\title{
Airborne observation of aerosol optical depth during ARCTAS: vertical profiles, inter-comparison and fine-mode fraction
}

\author{
Y. Shinozuka ${ }^{1,2}$, J. Redemann ${ }^{2}$, J. M. Livingston ${ }^{3}$, P. B. Russell ${ }^{4}$, A. D. Clarke ${ }^{5}$, S. G. Howell ${ }^{5}$, S. Freitag ${ }^{5}$, \\ N. T. O'Neill ${ }^{6}$, E. A. Reid ${ }^{7}$, R. Johnson ${ }^{4}$, S. Ramachandran ${ }^{1,8}$, C. S. McNaughton ${ }^{5}{ }^{*}$, V. N. Kapustin ${ }^{5}$, \\ V. Brekhovskikh ${ }^{5}$, B. N. Holben ${ }^{9}$, and L. J. B. McArthur ${ }^{10}$ \\ ${ }^{1}$ NASA Postdoctoral Program, NASA Ames Research Center, Moffett Field, California, USA \\ ${ }^{2}$ Bay Area Environmental Research Institute, Sonoma, California, USA \\ ${ }^{3}$ SRI International, Menlo Park, California, USA \\ ${ }^{4}$ NASA Ames Research Center, Moffett Field, California, USA \\ ${ }^{5}$ School of Ocean and Earth Science and Technology, University of Hawaii, Honolulu, Hawaii, USA \\ ${ }^{6}$ CARTEL, Université de Sherbrooke, Sherbrooke, Québec, Canada \\ ${ }^{7}$ Marine Meteorology Division, Naval Research Laboratory, Monterey, California, USA \\ ${ }^{8}$ Physical Research Laboratory, Ahmedabad, India \\ ${ }^{9}$ NASA Goddard Space Flight Center, Greenbelt, Maryland, USA \\ ${ }^{10}$ Environment Canada, Toronto, Ontario, Canada \\ *now at: Aina Kai Environmental, LLC, Aiea, Hawaii, USA
}

Received: 4 June 2010 - Published in Atmos. Chem. Phys. Discuss.: 2 August 2010

Revised: 9 January 2011 - Accepted: 18 January 2011 - Published: 20 April 2011

\begin{abstract}
We describe aerosol optical depth (AOD) measured during the Arctic Research of the Composition of the Troposphere from Aircraft and Satellites (ARCTAS) experiment, focusing on vertical profiles, inter-comparison with correlative observations and fine-mode fraction. Arctic haze observed in $<2 \mathrm{~km}$ and $2-4 \mathrm{~km}$ over Alaska in April 2008 originated mainly from anthropogenic emission and biomass burning, respectively, according to aerosol mass spectrometry and black carbon incandescence measurements. The Ångström exponent for these air masses is $1.4 \pm 0.3$ and $1.7 \pm 0.1$, respectively, when derived at $499 \mathrm{~nm}$ from a second-order polynomial fit to the AOD spectra measured with the 14-channel Ames Airborne Tracking Sunphotometer (AATS-14) over $354-2139 \mathrm{~nm}$. We examine 55 vertical profiles selected from all phases of the experiment. For two thirds of them, the AOD spectra are within $3 \%+0.02$ of the vertical integral of local visible-light scattering and absorption. The horizontal structure of smoke plumes from local biomass burning observed in central Canada in June and July 2008 explains most outliers. The differences in midvisible Ångström exponent are $<0.10$ for $63 \%$ of the profiles with 499-nm AOD $>0.1$. The retrieved fine-mode fraction
\end{abstract}

Correspondence to: Y. Shinozuka (yohei.shinozuka@nasa.gov) of AOD is mostly between 0.7 and 1.0, and its root mean square difference (in both directions) from column-integral submicron fraction (measured with nephelometers, absorption photometers and an impactor) is 0.12 . These AOD measurements from the NASA P-3 aircraft, after compensation for below-aircraft light attenuation by vertical extrapolation, mostly fall within \pm 0.02 of AERONET ground-based measurements between $340-1640 \mathrm{~nm}$ for five overpass events.

\section{Introduction}

The 14-channel Ames Airborne Tracking Sunphotometer (AATS-14) measures aerosol optical depth (AOD)

- from airborne platforms

- with a small and well-documented error $(\sim 0.01$; see Sect. 2.1)

- over a wide spectral range.

These three features have facilitated the interpretation and validation of satellite-based observations (Levy et al., 2003; Livingston et al., 2003, 2009; Gassó and Hegg, 2003; Chu et al., 2005; Russell et al., 2005, 2007; Redemann et al., 2005, 2006, 2009a, b) and the estimation of local aerosol radiative effects (Russell et al., 1999, 2010; Bergstrom et al., 2005,

Published by Copernicus Publications on behalf of the European Geosciences Union. 
2006, 2007, 2009; Redemann et al., 2006). They stimulate another three applications.

First, the aircraft deployment of AATS-14 can yield AOD profiles over areas with scarce alternative measurements. Northern North America is among such areas, with the sporadic presence of ground sites and, due to the large areas of bright surface and frequent clouds, a limited number of satellite retrievals. Airborne remote-sensing with AATS-14 over the region, particularly when accompanied by in situ measurements, provides an effective rapid assessment of local airmass characteristics.

Second, its well-documented low uncertainties and wide spectral coverage make AATS-14 AOD a useful parameter for comparison with other suborbital measurements. AATS14 is one of the very few airborne sensors that can measure AOD at $2.1 \mu \mathrm{m}$ (e.g., Levy et al., 2005; Redemann et al., 2005). AATS-14's spectral range covers all but the $340 \mathrm{~nm}$ channel of the Cimel sunphotometers used by the AERONET ground-based sunphotometer network. Altitude resolved AOD isolates light extinction for a certain layer and can be compared with coincident in situ airborne measurements. Through these comparisons, one can not only assess the performance of optical instruments, but also link measurements of aerosol physical and chemical properties between platforms (e.g., aircraft and ground) and between domains (column integral and local, ephemeral and continuous).

Third, the wide spectral coverage of AATS-14 can be exploited to derive fine-mode fraction (FMF), the fraction of AOD contributed by the algorithmically-defined fine mode (O'Neill et al., 2001, 2003). Kaufman et al. (2002) argue that the ability of satellites to observe the spatial distribution of aerosols, and to distinguish fine from coarse particles, can be exploited to separate natural from anthropogenic aerosols. This argument does not completely hold when fine particles from naturally occurring forest fires dominate extinction. Still, comparing the AATS-14 FMF with in situ aerosol properties will enable rough evaluation of the remote sensing product. To our knowledge, only Anderson et al. (2005) and Gassó and O'Neill (2006) have made such comparisons. They used the submicron fraction (SMF) of in situ extinction, measured using a $1-\mu \mathrm{m}$ impactor. FMF comparison among remote sensing instruments has been only slightly more common (Kleidman et al., 2005; Jethva et al., 2005, 2007; Ramachandran, 2007; Redemann et al., 2009a).

This paper addresses these three subjects (Sect. 3.1-3.3, respectively) using the AOD observed during the Arctic Research of the Composition of the Troposphere from Aircraft and Satellites (ARCTAS) experiment. This multi-platform campaign took place primarily in Alaska, USA in March and April 2008, California, USA in June 2008, and Saskatchewan and Alberta, Canada in June and July 2008 (Fig. 1). The NASA P-3 aircraft, on which AATS-14 and in situ instruments were deployed, sampled boreal forest fire smoke, Asian outflow, and emissions from mining sites among other air masses. An overview of the ARCTAS experiment and the

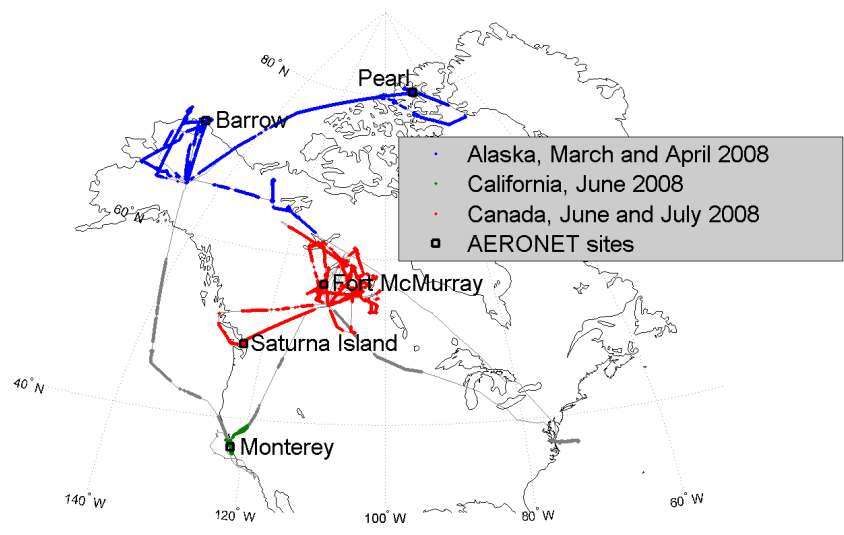

Fig. 1. The flight track of NASA P-3 aircraft during ARCTAS separated into three geographical groups, and AERONET ground sites mentioned in this paper.

multiple platforms involved is given by Jacob et al. (2010), and its meteorology is reviewed by Fuelberg et al. (2010).

\section{Instrumentation and methods}

\subsection{Airborne remote sensing with AATS-14}

AATS-14 data acquisition, screening, calibration, reduction and uncertainty analysis are described below. They are similar to previous deployments of this instrument and its predecessor (Matsumoto et al., 1987; Russell et al., 1993a, b, 1999 , 2007; Schmid and Wehrli, 1995; Schmid et al., 1996, 1998, 2001, 2003a; Livingston et al., 2003, 2005, 2007, 2009; Redemann et al., 2003, 2005, 2009a, b). Ångström exponent and layer AOD are derived in Sects. 3.1.1 and 3.2.1, respectively.

AATS-14 measures direct solar beam transmission in narrow wavelength channels by using detectors in a tracking head mounted externally to the aircraft. The sampling is at $3 \mathrm{~Hz}$, and every $4 \mathrm{~s}$ AATS-14 records detector voltages consisting of an average and standard deviation of 9 samples taken during the first 3 of the $4 \mathrm{~s}$. These data are stored together with those on instrument tracking, temperature control and aircraft location as well as ambient temperature, relative humidity (RH) and static pressure.

The standard deviations of all channels were used subsequently in a cloud-screening algorithm, as described by Schmid et al. (2003a) and Redemann et al. (2009a). As Redemann et al. (2009a) pointed out, the AATS cloud screening method does not rely solely on the spatial varibility of its transmission measurements. Instead, as long as the AATS instrument maintains tracking of the solar disk through or near a cloud, the Ångström exponent of the optical depth retrievals is a second test of the effectiveness of the cloud screening method. In this test, the variability of the Ångström exponent is used to decide whether a feature that shows large 
spatial variability is likely a cloud or an aerosol plume. If, for example, a feature shows large transmission variability and shows a decrease in Ångström exponent, we conclude that the feature is likely a cloud and the feature is flagged accordingly. If, on the other hand, a feature shows large transmission variability but no change in Ångström exponent when compared to adjacent measurements, we conclude that the feature is an aerosol plume. We concede that our method may unintentionally filter out some cases of heavy smoke during the Canada phase of ARCTAS. We concede further that our method may contain remnants of cirrus cloud contamination if the optical depth of such cirrus clouds is small enough so as to not affect the Ångström exponent calculations of the combined aerosol-cirrus optical depth significantly. In one case during ARCTAS-spring, namely on 9 April 2008 at $21: 15 \mathrm{UT}$, near $74^{\circ} \mathrm{N}$ and $139^{\circ} \mathrm{E}$, we encountered a feature that showed relatively large variability in transmission, but relatively slow changes in Ångström exponent. Given the conditions of the spring phase, it is likely that this feature is a spatially highly homogeneous cirrus cloud, with spatial homogeneity unmatched at lower latitudes. The total optical depth of this feature is of the order of 0.2-0.3 and given its isolated nature it has no bearing on the further analysis in this paper. During no other ARCTAS-spring flight did we find features of similar high variability in transmission, but low variability in calculated Ångström exponent. Therefore, we estimate such cirrus contaminations to be possible at levels of $10 \%$ of AOD, generally equivalent to optical depths of $0.01-$ 0.02 or less. A potentially large source of calibration error is dirt deposited on the Sunphotometer entrance window (e.g., Livingston et al., 2003). To minimize this error we cleaned the window carefully before each flight. Data obviously affected by frost, dirt and adhesive particles, as indicated by abrupt changes in transmission measured in individual channels and resulting small transmissions (large derived AOD) during high altitude legs, were removed.

This paper examines the AATS-14 data collected on 20 of the 25 ARCTAS flights. Excluded are three transit flights, one science flight when dirt accumulated on the AATS14 quartz window during low level legs, and one science flight when cloud conditions were unfavorable for AATS data collection.

The 14 channels are centered at wavelengths $353.5,380.0$, $452.6,499.4,519.4,605.8,675.1,779.1,864.5,940.6$, $1019.1,1241.3,1558.5$, and $2139.3 \mathrm{~nm}$, with full-width halfmaximum bandwidths of 2.0, 4.6, 5.6, 5.4, 5.4, 4.1, 5.2, 4.7, 5.0, 5.0, 5.1, 5.1 4.7, and $17.3 \mathrm{~nm}$, respectively, for the spring phase. For the summer phase, three of the filters were replaced with new ones with similar center wavelengths (451.2, 520.4 , and $2139.1 \mathrm{~nm}$ ) and half-maximum bandwidths (5.7, 5.2 , and $15.2 \mathrm{~nm}$ ). These channels permit separation of aerosol, water vapor, and, for measurements acquired at low solar elevation angles with small AOD (Livingston et al., 2005), ozone attenuation along the slant path from the Sun to the instrument. Because most AATS measurements during
ARCTAS did not satisfy the solar elevation angle and AOD criteria required for retrieval of ozone slant or column attenuation, the ozone column contents were extracted from the Ozone Monitoring Instrument (OMI) archived retrieval files and adjusted for the P-3B altitude using the 1976 standard ozone model vertical distribution. This procedure is the same as that reported in previous AATS studies (e.g., Livingston et al., 2007, 2009). We retrieved AOD at all the wavelengths except $940.6 \mathrm{~nm}$ from the slant-path transmissions using the methodology described in detail previously (e.g., Russell et al., 1993a). Exoatmospheric detector voltages required for these AOD retrievals were calculated by first applying the Langley plot technique (Schmid and Wehrli, 1995) to sunrise measurements acquired at Mauna Loa Observatory, Hawaii, in February, May, and August 2008 (thus bracketing the ARCTAS campaign) and then, following the procedure described in Schmid et al. (2003a, b), by analysis of high altitude clear air AOD spectra obtained during the spring and summer deployments.

Through its non-zero $\left( \pm 1.85^{\circ}\right.$ of the axis) field of view, the AATS-14 receives some diffuse light in addition to the direct solar beam. As a result, uncorrected sunphotometer measurements can overestimate direct-beam transmission and hence underestimate the AOD. This effect increases with decreasing wavelength and increasing particle size. We estimated these diffuse light effects using formulations derived by Russell et al. (2004), which are applicable over a wide range of column particle size distributions. These effects were negligible in ARCTAS because of the relatively large Ångström exponents (see Sects. 3.1.1 and 3.3.1), indicating relatively small particles with relatively small forward scattering fractions.

AATS-14 data were corrected for Rayleigh scattering and absorption by $\mathrm{O}_{3}, \mathrm{NO}_{2}, \mathrm{H}_{2} \mathrm{O}$ and $\mathrm{O}_{2}-\mathrm{O}_{2}$ after Schmid et al. (2006).

Uncertainties in AATS-derived AOD were calculated using an expression based on Eq. (A22) of Russell et al. (1993a), with additional terms added to account for (1) tracking errors combined with a sloping angular response within each channel's field of view (FOV) and (2) uncertainties in $\mathrm{O}_{2}-\mathrm{O}_{2}$ absorption. An additional potential source of AOD error, mentioned above, is contamination (e.g., condensation, frost, or dirt) deposited on the AATS front window. We do not expand error bars to account for this potential error. Instead, as noted above, we inspect individual AOD spectra, together with environmental conditions (e.g., temperature and airmass), in an effort to identify and remove cases likely to have such contamination. As a test of the adequacy of our AOD error bars, we have calculated the root-mean-square (rms) difference between data points and a second-order polynomial fit to the points for high altitude spectra measured during 8 flights in Spring and 9 in Summer. In general, we found that these rms differences were $<0.008$ in nearly all cases. 


\subsection{Airborne in-situ measurements of aerosol optical and chemical properties}

Total and submicrometer aerosol scattering coefficients were measured at 450, 550 and $700 \mathrm{~nm}$ with two TSI model 3563 integrating nephelometers (Anderson et al., 1996, 2003; Heintzenberg and Charlson, 1996). The measurements were made every second but represent an average over about $5 \mathrm{~s}$, the residence time of aerosols in the chamber. The instrument RH was not actively controlled but kept to $<30 \%$, often near $20 \%$, by ram heating and cabin temperatures higher than the ambient. Measurement accuracy and 300-secondaverage precision are estimated to be $2 \%$ and $0.2 \mathrm{Mm}^{-1}$, respectively (McNaughton et al., 2009). The light scattering values measured over the detection angles of $7-170^{\circ}$ were corrected to $0-180^{\circ}$ after Anderson and Ogren (1998). The angular truncation correction was $5-11 \%$ and only mildly uncertain (1\%) for most time periods during ARCTAS, because coarse particles contributed a minor fraction of scattering.

Two 3-wavelength Radiance Research particle soot absorption photometers (PSAP) continuously measured aerosol light absorption by monitoring the change in transmittance across a filter using 3 LEDs $(470,530$ and $660 \mathrm{~nm})$. We correct our data for the scattering artifact as well as calibration error after Virkkula (2010), an erratum for Virkkula et al. (2005). This correction, a function of the ratio of the scattering coefficient to the extinction coefficient (i.e., single scattering albedo, SSA) and the wavelength, reduces 530$\mathrm{nm}$ absorption nearly as much as does the classic correction scheme widely used for a single-wavelength prototype of the PSAP (Bond et al., 1999). We assume the uncertainty for absorption coefficient is $20 \%$. The average instrument noise, computed as the average standard deviation for six 300 -second (5-minute) averages of the $1-\mathrm{Hz}$ data taken in our laboratory for filtered air, is $0.56 \mathrm{Mm}^{-1}$ for all wavelengths (McNaughton et al., 2009).

Two single-wavelength Radiance Research model M903 nephelometers were operated in parallel to measure the effect of humidity on aerosol scattering. They were modified with Corion CA-550 $80 \mathrm{~nm}$ bandpass filters for an approximate operating wavelength of $540 \pm 3 \mathrm{~nm}$ (Anderson et al., 2003). One was controlled to about $80 \%$ RH (RH1) and the other at $<40 \%$ (RH2) (Howell et al., 2006). Anderson et al. (2003) estimate that the noise averaged over $4 \mathrm{~min}$ is $0.46-0.58 \mathrm{Mm}^{-1}$. The wet to dry scattering ratio, $f(\mathrm{RH})$, was used to calculate $\gamma$ based on the following equation.

$f(\mathrm{RH})=((1-\mathrm{RH} 1 / 100) /(1-\mathrm{RH} 2 / 100))^{-\gamma}$.

$\gamma$ characterizes the response in aerosol scattering to changes in RH, which is determined by the aerosol chemistry, mixing state, sizes and refractive index. Using the calculated $\gamma$, we can derive $f(\mathrm{RH})$ for the ambient $\mathrm{RH}$, or $f(\mathrm{ambRH})$, by replacing RH1 and RH2 with the measured ambient RH and the TSI nephelometer RH $(<30 \%)$, respectively. The resulting $f(\mathrm{ambRH})$, when multiplied by the total dry scattering coefficient, gives the scattering coefficient at ambient RH. The errors in $\gamma$ and $f(\mathrm{ambRH})$ were estimated by assuming a 3.5\% error in RH measurement (Anderson et al., 2003) and a 5\% random error in each Radiance Research nephelometer scattering measurement. These errors confined $\gamma$ within $18 \%$ of the true value for a true value of 0.4 , and within $14 \%$ for a true value of 0.6. The resulting relative error in $f(\mathrm{ambRH})$ is below $10 \%$ for drier air typical for the ARCTAS study regions $(<70 \% \mathrm{RH})$, while it exceeds $20 \%$ at $90 \%$ ambient $\mathrm{RH}$ for moderately hygroscopic particles $(\gamma>0.3)$.

The in situ measurements described so far can be integrated vertically to yield layer AOD (Sect. 3.2.1). A second combination of a TSI nephelometer and a PSAP was operated similarly but behind a $1-\mu \mathrm{m}$ (aerodynamic diameter) impactor to measure submicron fraction of scattering and absorption, which is mentioned in Sect. 3.3.2.

An Aerodyne High-Resolution Time of Flight Aerosol Mass Spectrometer (AMS) characterized volatile ionic and organic components of aerosols between 50-700 nm (DeCarlo et al., 2006; Canagaratna et al., 2007). During ARCTAS it was generally operated in V-mode (high sensitivity) rather than W-mode (high mass resolution), with the heater set to about $600^{\circ} \mathrm{C}$. This paper uses bulk composition only, not resolved for aerosol size. To keep steadier sampling rates the AMS inlet was preceded by an orifice and a chamber regulated to $600 \mathrm{hPa}$ at low altitudes and $300 \mathrm{hPa}$ at high altitude. Ionization and sampling efficiency were calibrated with ammonium nitrate particles sized with a differential mobility analyzer. Data analyses were performed with techniques documented in Allan et al. (2004).

A Single Particle Soot Photometer (SP2) measured laserinduced incandescence to detect black carbon (soot) mass (Stephens et al., 2003; Schwartz et al., 2006) between about $100-600 \mathrm{~nm}$.

In situ data affected by clouds were identified based on the ambient humidity record and flight notes, and omitted from further analysis here. Loss of particles in inlet and tubing is expected to be negligible for all in situ instruments, because extinction observed during ARCTAS was mostly contributed by fine particles. Possible exceptions are a few high altitude legs with the presence of dust particles and low level legs over the oceans with the presence of sea salt particles.

\subsection{Ground-based remote sensing with AERONET Sun-sky photometer and micropulse lidar}

The Aerosol Robotic Network (AERONET) consists of automatic tracking Sun-sky photometers located at $\sim 400$ ground sites around the world. These instruments measure AOD, which is routinely archived together with spectrum-based fine-mode fraction and inversion products (Holben et al., 1998, 2001; Eck et al., 2001; O'Neill et al., 2001; Dubovik et al., 2002) after application of the cloud screening and quality control procedures described by Smirnov et al. (2000). Measurements of spectral AOD used in this study were acquired 
through their standard data acquisition method with a time interval of 2-15 min at eight wavelengths: $340,380,440$, $500,675,870,1020$ and $1640 \mathrm{~nm}$. Only level 2.0 products are used in this study. The locations of AERONET sites mentioned in this paper (Barrow, Pearl, Monterey, Fort McMurray and Saturna Island) are marked in Fig. 1.

The MicroPulse Lidar Network (MPLNET) consists of ground-based 523, 527, or $532 \mathrm{~nm}$ backscatter micropulse lidar systems (MPL's) providing vertical atmospheric profiles of aerosols and clouds up to $30 \mathrm{~km}$ with a temporal and vertical resolution of $1 \mathrm{~min}$ and $75 \mathrm{~m}$ respectively (Welton et al., 2001). When collocated with AERONET Sun-sky photometers, the MPL's corrected backscatter data can be iterated to derive extinction by normalizing the MPL extinction profiles to AERONET derived AOD at the MPL wavelength $(527 \mathrm{~nm}$ for Monterey, California) (Campbell et al., 2002; Welton and Campbell, 2002; Eck et al., 1999).

\section{Results and discussion}

\subsection{Vertical profile}

Here is an overview of our AOD observations during ARCTAS. We mainly sampled Asian outflow over Alaska, combination of biomass burning and marine aerosols over California, and smoke from local forest fires over central Canada.

\subsubsection{Alaska, April}

During the spring phase, $\mathrm{P}-3$ science flights during the period $1-15$ April 2008 over Alaska, the Arctic Ocean, and Greenland yielded AODs that were confined to a fairly narrow range (Fig. 2a). The baseline AOD (open circles in Fig. 2a), defined as the 5 th percentile among the valid data averaged in each $100 \mathrm{~m}$ altitude bin, decreased constantly from 0.07 near the surface to 0.01 at $7500 \mathrm{~m}$ (GPS altitude) at $499 \mathrm{~nm}$. The $\mathrm{AOD}_{499}$ seldom exceeded 0.15 even as we pursued enhanced aerosol concentrations. These values are within the range of ground-based AOD observed during the same time period (Saha et al., 2010) and airborne sunphotometry conducted a year later (Stone et al., 2010), both over the same area.

The wavelength dependence of AOD gives insight into the observed aerosol types. We derive it in two steps. First, the function $\ln \mathrm{AOD}=a_{2}(\ln \lambda)^{2}+a_{1} \ln \lambda+a_{0}$ is fitted to each AOD spectrum. Second, the resulting curve is differentiated into modified Ångström exponent: $A_{\lambda}=-d \ln (\mathrm{AOD}) / d \ln \lambda=-2 a_{2} \ln \lambda-a_{1}$. Advantages of the second-order polynomial fit will be illuminated in Sect. 3.3. Note that the AATS-14 measurements represent the air above the aircraft, not just that surrounding the aircraft.

The modified Ångström exponent of AOD at $499 \mathrm{~nm}$, $A_{499}$, observed during the spring phase is represented by the color in Fig. 2a. This can be classified into three groups loosely separated by altitude and geographical location. $A_{499}$
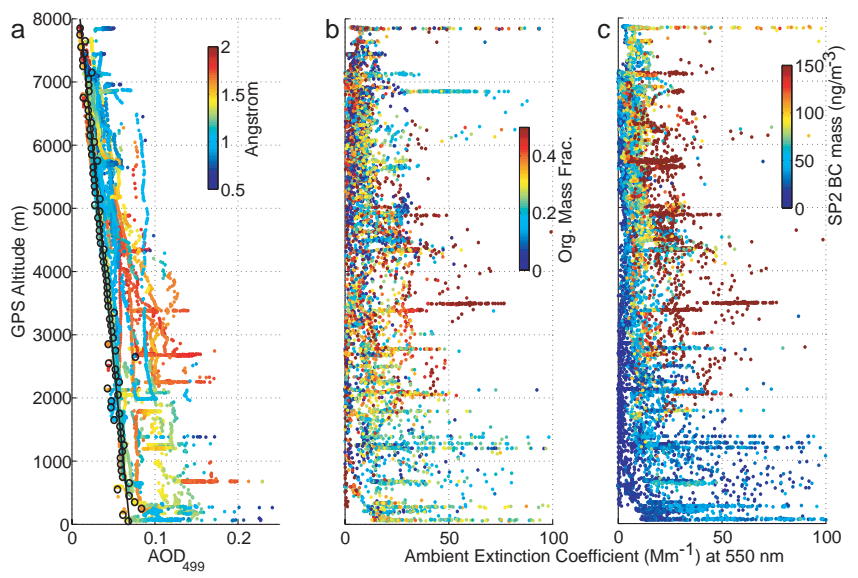

Fig. 2. Vertical profiles of AOD at $499 \mathrm{~nm}$ (a) and ambient extinction coefficient $\left(\mathrm{Mm}^{-1}\right)$ at $550 \mathrm{~nm}(\mathbf{b}, \mathbf{c})$ color-coded with (a) the AOD Ångström exponent at $499 \mathrm{~nm}$, (b) organic fraction of nonrefractory mass of submicron particles and (c) the black carbon mass at standard temperature and pressure, for the Alaska phase. These data from 1-15 April 2008 are averaged over $3 \mathrm{~s}$ for (a), $10 \mathrm{~s}$ for (b) and (c). In (a) the 5th percentile in each 100-m altitude bin is marked with circle, and its linear regression with black line.

values as low as $\sim 0.7$ were recorded occasionally during two legs, 70 and $1400 \mathrm{~m}$ above the Arctic Sea to the north of Canada. They were low presumably because of either dust or ice particles. These two are difficult to separate, but we estimate the contribution of ice particles to be $0.01-0.02$ at most (see Sect. 2.1 and references for our cloud screening method). The ocean surface was nearly entirely covered by ice such that few sea salt particles could be generated. High $A_{499}$ values $(1.7 \pm 0.1)$ were observed mostly between 2-4 km GPS altitude on 13 and 15 April. They were associated with relatively large AOD values - twice the baseline values or greater. For other samples $A_{499}$ was $1.4 \pm 0.3$ (mean \pm standard deviation).

The high $(1.7 \pm 0.1)$ Ångström exponent group appears to arise from forest fires. According to the AMS measurements (Fig. 2b), organic mass concentration was high relative to other non-refractory aerosol components (mainly sulfate) in the air masses between $2-4 \mathrm{~km}$ with high AOD that comprises the high Ångström exponent group. The black carbon mass measured with SP2 also tended to be high (Fig. 2c, see also McNaughton et al., 2011). Cloud contamination (including cirrus) is unlikely as we screened data based on both spatial variability and Ångström exponent (Sect. 2.1). These pieces of evidence support the inference that the air masses in the lower free troposphere with high AOD originated from biomass burning.

Our 15-day observation in this area does not provide any proof that the vertical structure persisted throughout the spring. However, our observation is generally consistent with previous studies in the same area in spring. Observations 
from other research aircraft and the Lagrangian particle dispersion model FLEXPART consistently indicated transport of the Siberian fire emissions to our study area during the same time period (Warneke et al., 2010). While our data indicate these features to be most pronounced on 15 April and confined to $2-4 \mathrm{~km}$, the results published by Warneke et al. (2010), based on the transport of pollution simulated since 20 days prior, show the Siberian influence was present at higher altitudes too, depending on latitude. Meanwhile, the background, i.e., almost the entire flight paths in the layer up to $2 \mathrm{~km}$ and the segments in the free troposphere with relatively low AOD, had higher fraction of sulfate. Airmasses with a high sulfate concentration were observed in the same area, altitude and season in the past; they are considered to have been influenced by anthropogenic pollution from Eurasia (Radke et al., 1984; Scheuer et al., 2003).

The middle (1.4 \pm 0.3$)$ Ångström exponent group appears to be anthropogenic pollution. The inorganic content is relatively high near the surface; so it is in the lower troposphere when AOD is near the background values (Fig. 2b). Other potential sources of aerosols include nucleation at cloud tops followed by subsidence (Clarke et al., 1998; Garrett et al. 2002) and open leads (Ferek et al., 1995). However, unlike anthropogenic pollution, these sources account for only a minor contribution to the total aerosol in winter and spring (Garrett et al., 2004 and references therein).

Arctic haze, a term frequently used for relatively high light extinction over this region, may thus refer to either of the two different aerosol types residing individually in the boundary layer and lower free troposphere. Continuous monitoring of spectral AOD over the Arctic region, especially if resolved for altitude, would allow for a more statistically robust assessment as to how ubiquitously this separation occurs.

\subsubsection{California, June}

In the summer phase the P-3 aircraft flew over California on 22 and 24 June 2008, before transiting to central Canada on 26 June.

The first California flight included a vertical profile through multiple aerosol layers over Monterey during the period 19:04-19:36 UTC on 22 June (Fig. 3). A biomass burning smoke layer was observed between $250-580 \mathrm{~m}$ GPS altitude. It was marked by high ambient extinction $\left(>500 \mathrm{Mm}^{-1}\right.$ at $\left.550 \mathrm{~nm}\right)$, low $(\sim 20 \%)$ relative humidity, and high (>2.0) in situ extinction Ångström exponent. The profile also sampled the marine boundary layer (MBL, $<250 \mathrm{~m}$ ) marked by high RH ( 90\%) and low extinction Ångström exponent $(\sim 1.2)$. It also penetrated a less polluted layer (1200-3210 m). The MBL contributed 1-3 times as much AOD as the smoke at $1019.1-2139.1 \mathrm{~nm}$, much more than its negligible share at shorter wavelengths.
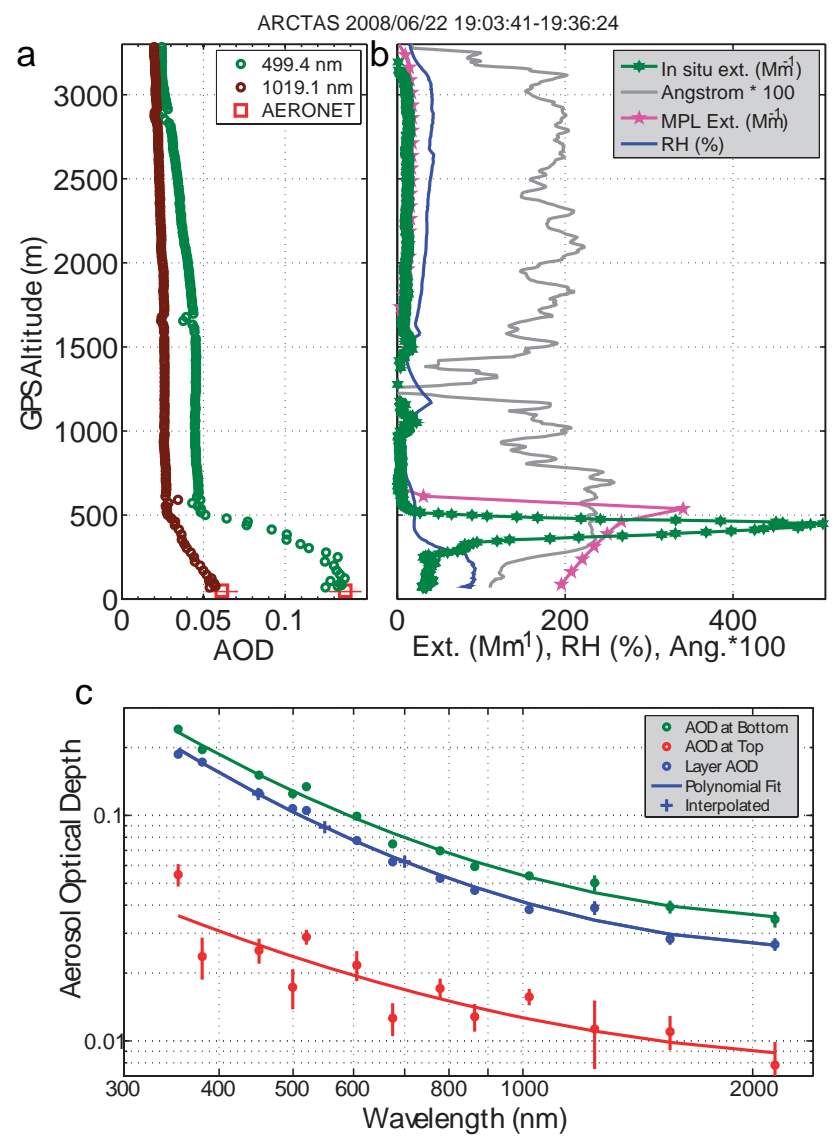

Fig. 3. (a) Vertical profile of above-aircraft AOD observed during the spiral over Monterey on 19:03:41-19:36:24, 22 June 2008. (b) In situ extinction coefficient and its Ångström exponent during the same ascending profile. The micropulse lidar (MPL) extinction coefficient and ambient RH are also shown. (c) AOD spectra observed at the bottom and top of profile. Their difference (layer AOD), a second-order polynomial fit and the values interpolated to the nephelometer wavelengths are also shown. The fit is $\ln \mathrm{AOD}=0.51(\ln \lambda)^{2}-0.97 \ln \lambda-3.19$ where $\lambda$ is the wavelength in $\mu \mathrm{m}$.

The second California flight resulted in a very limited set of valid AOD data because of dirt on the AATS-14 window. The 26 June transit flight included extensive measurements of wildfire smoke over the California Central Valley and Lake Tahoe.

\subsubsection{Canada, June and July}

The rest of the summer phase, from the end of 26 June to 12 July, encompassed central Canada. The P-3 repeatedly sampled intense smoke from local forest fires. They were often observed right below NASA P-3 during the flights, in contrast to the smoke from distant Siberian forest fires sampled during the spring phase. The AOD was generally much higher and, as we demonstrate in Sect. 3.2.1, more 


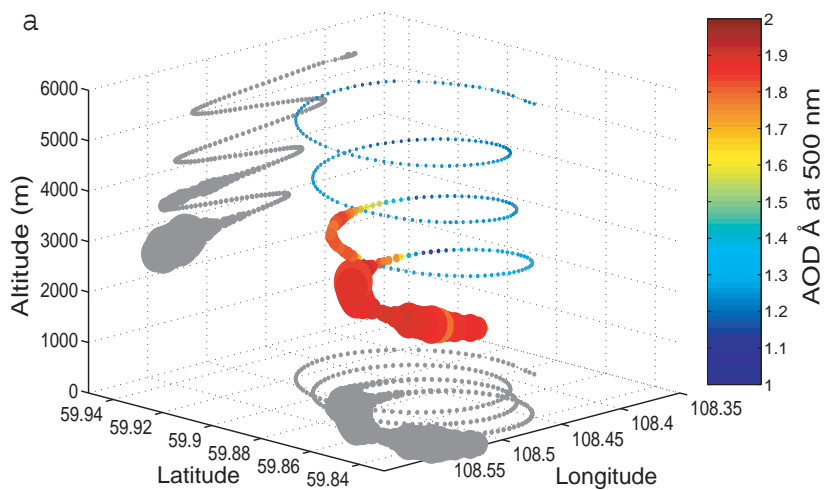

$\mathrm{b}$

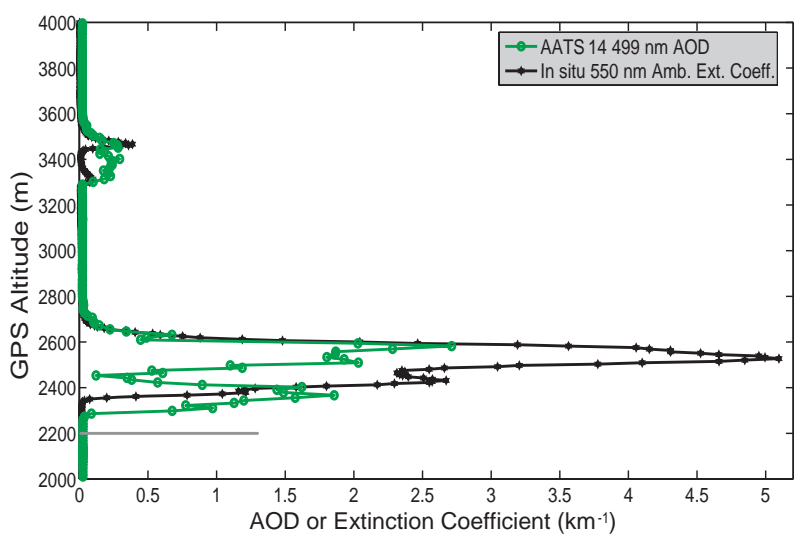

Fig. 4. (a) The spiral flown on 10 July, 21:27-21:37, north of Lake Athabasca. Marker size is proportional to the AOD at $499.4 \mathrm{~nm}$, which went up to 2.7. The same flight track is projected on two planes in grey. The smoke plume was located on the western edge of the $\sim 6-\mathrm{km}$-wide spiral up to $\sim 3500 \mathrm{~m}$. (b) AATS-14 AOD at $499.4 \mathrm{~nm}$ (green) and in situ (neph+PSAP) extinction coefficient at $550 \mathrm{~nm}$ in $\mathrm{km}^{-1}$ between $2000-4000 \mathrm{~m}$ (GPS altitude) of the vertical profile. The grey horizontal bar indicates the variability measure used in Fig. 5.

variable than the values observed over Alaska and the Arctic Ocean in the spring. AOD 499 frequently exceeded 1 and at times reached 4 , accompanied by extremely high concentration of carbon monoxide (well above 5 ppm). $A_{499}$ was 2.2-2.3 for the smoke observed on 30 June and 6 July, and smaller in the equally intense smoke observed on 2 July (1.82.2 ) and 10 July (1.8-1.9). These values did not noticeably change between white smoke from smoldering fires (in situ SSA at $550 \mathrm{~nm}$ 0.90-0.95) and black smoke from flaring ones (SSA550 0.80-0.90).

One example case with high horizontal variability is the smoke from the Camsell and Viking fires north of Lake Athabasca sampled during the period 21:27-21:37 on 10 July (Fig. 4) during a spiral ascent. A smoke plume touched the western edge of the spiral up to $\sim 3500 \mathrm{~m}$. The AOD measured near the bottom of the profile varied even more significantly than that observed during the Monterey profile:
$\mathrm{AOD}_{499}$ (for the air column above the aircraft) changed by 2.6, and the local ambient extinction coefficient at $550 \mathrm{~nm}$ between 20 and $5000 \mathrm{Mm}^{-1}\left(0.02-5 \mathrm{~km}^{-1}\right)$ within the $\sim 6$ $\mathrm{km}$-diameter spiral. The low AOD to the east of $108.48^{\circ} \mathrm{W}$ throughout the column (see the projection to the bottom plane of the figure) testifies to the variability in the horizontal direction, not just in the vertical. The NASA P-3 aircraft repeatedly encountered smoke with similarly high and variable AOD over Saskatchewan and Alberta. A companion paper (Redemann et al., 2009, a journal article in preparation) provides a detailed analysis on the forest fire plumes observed on 30 June 2008 from multiple ARCTAS platforms.

In an outflow of smoke with no distinguishable plume, the AOD did not vary as dramatically, in either horizontal or vertical direction. In an example of such events, AOD $_{499}$ varied by only 0.03 (14\% of the average near $500 \mathrm{~m}$ altitude) at each altitude over more than $200 \mathrm{~km}$ of horizontal extent around Fort McMurray during the period 17:20-20:50 on 3 July (Fig. S1 in Supplement).

At long distances away from smoke, $\mathrm{SSA}_{550}$ was usually between 0.95-1, AOD 499 0.01-0.1, and A499 1.3-1.7. One air mass encountered on 9 July, which may or may not have been influenced by smoke, exhibited an odd combination of low SSA $_{550}(0.92-0.95)$ and low $A_{499}$ (centered at 1.4). The in situ scattering Ångström exponent was near 0 briefly on 29 June, 9-10 July, likely because of dust.

\subsection{AOD comparisons among airborne and ground- based observations}

\subsubsection{Airborne remote sensing (AATS-14) and in-situ observations (neph and PSAP) of layer AOD spectra}

Here we derive layer AOD from two types of airborne measurements individually: remote sensing from the AATS-14 and the in situ measurements with the nephelometers and PSAPs. We illustrate the methodologies with an example vertical profile, show the results from the entire campaign, and explain the layer AOD differences between the two methods.

The remote-sensing based layer AOD, shown with blue circles in Fig. 3c for the Monterey profile, is the difference in AATS-14 AOD between the bottom (green circle) and top (red) of the vertical profile. The blue crosses represent the layer AOD linearly interpolated in log-log space to the nephelometer wavelengths. The root-sum-square of half of the total AOD uncertainties (instrumental plus tracking, Sect. 2.1) at the top and the bottom of a given profile is assumed to be the uncertainty intrinsic to the instrument (excluding the impact of horizontal variability in aerosol loading), after Eq. (6) of Redemann et al. (2003):

$\delta_{r} \tau=\sqrt{\left(\delta \tau\left(z_{1}\right) / 2\right)^{2}+\left(\delta \tau\left(z_{2}\right) / 2\right)^{2}}$. 
Deriving layer AOD from the dry in situ measurements involves an estimation of the extinction coefficients at ambient conditions and integrating the result over altitude. The scattering coefficient of dry aerosols measured with the TSI nephelometer operated without an impactor was corrected for the angular truncation (Sect. 2.2). It was then adjusted to the ambient relative humidity recorded by the P-3 Data System, using the simultaneously measured humidity response (Sect. 2.2). The resulting ambient scattering coefficient was added to the PSAP absorption coefficient to yield the ambient extinction coefficient (dark green curve in Fig. 3b). Its integral over altitude is the in-situ derived layer AOD.

Uncertainty in the integral layer AOD arises from the $f(\mathrm{RH})$ estimate $(<10 \%$, Sect. 2.2), truncation correction (1\%, Sect. 2.2), nephelometer calibration ( $2 \%$, McNaughton et al., 2009) and PSAP correction (probably $\sim 2 \%$ or less; minor because absorption is minor relative to extinction). For low AOD, instrument noise becomes prominent too. It is estimated to be near 0.0005 . We treat these factors as if they were completely independent of each other, a reasonable approximation though inexact if truncation correction and $f(\mathrm{RH})$ estimate are both dependent on particle size.

The relative uncertainty estimated for the extinction coefficient (before vertical integration) is sometimes enormous $(>1000 \%)$ when the absolute value of extinction is small $\left(\sim 0.1 \mathrm{Mm}^{-1}\right)$. The data below the lower detection limit were included in the AOD calculation because eliminating them would bias the results low and shorten many vertical profiles. Small extinction coefficients were recorded typically in the free troposphere, above a more scattering/absorbing layer. In such cases the uncertainty from the weak extinction layer is often negligible relative to that from the more turbid lower layer in absolute terms.

Vertical profiles were adjusted and screened according to the following criteria for the layer AOD comparison. Each end of the profile was shortened until the point where a valid in situ measurement and a valid AATS measurement were made within $\pm 25 \mathrm{~m}$ altitude and $\pm 5 \mathrm{~s}$. This time period corresponds to $0.6 \mathrm{~km}$ or less in horizontal distance. In order to reduce the effect of horizontal inhomogeneity, we required the entire profile to remain within $50 \mathrm{~km}$ horizontally of both top and bottom ends. This eliminated a few spiral and hairpin-shaped ascents/descents, and most ramped ones. Those with elevation gain/loss of $<1 \mathrm{~km}$ were excluded as well.

Figure 5 shows the comparison of resulting layer AODs thus derived independently from airborne remote-sensing and in-situ measurements. They agree within $3 \%+0.02$ of each other for two thirds of the $55 \mathrm{P}-3$ vertical profiles.

The uncertainty in in-situ derived layer AOD is larger than, or comparable with, the uncertainty of the AATS-14derived layer AOD for most cases with the AATS-14 layer AOD $>0.03$. This is not discernible in the log-scale figure, because the uncertainty is small relative to the center value.

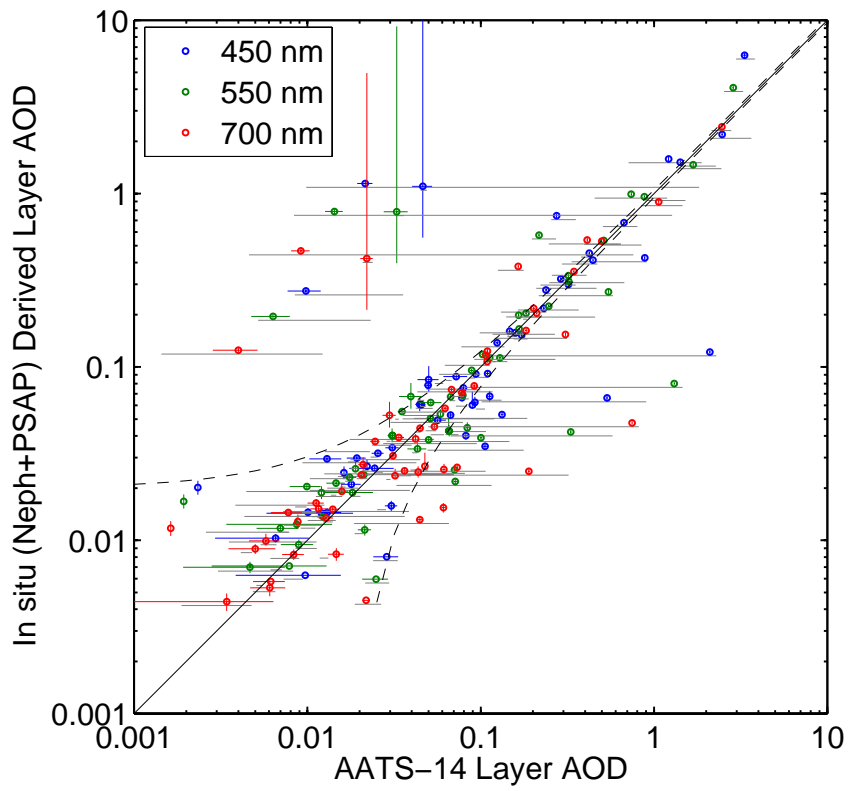

Fig. 5. Comparison of layer AODs derived by two methods. Plotted on the horizontal axis is the difference in AATS-14 AOD measured at two altitudes and interpolated to the nephelometer wavelengths of 450 (blue marker), 550 (green) and 700 (red) nm. On the vertical axis, the vertical integral of in situ scattering and absorption coefficients measured with nephelometer and PSAP is plotted. The solid and dashed black curves indicate the 1:1 correspondence and $\pm(3 \%+0.02)$ deviation, respectively. The colored horizontal and vertical lines associated with data points indicate estimated measurement uncertainties. The effect of spatial variability is indicated separately with grey horizontal lines. This represents the center $68 \%$ values of AOD at the bottom layer minus the snapshot top value, and does not necessarily include the snapshot layer AOD value (circle).

The humidification effect often contributes a large error in this type of closure experiment. But the generally low ambient RH and moderate particle hygroscopicity during ARCTAS resulted in the good agreement found here. There is an exception indicated with long vertical error bars in Fig. 5. This profile was flown near clouds and associated with ambient $\mathrm{RH}>97 \%$ and a calculated $f(\mathrm{ambRH})$ of $\sim 50$.

Generally speaking, the horizontal variability in aerosols and clouds can cause disagreement between remote-sensing and in-situ derived layer AODs. The AATS-14 and in situ instruments measure along different paths, i.e., the slant path towards the Sun and the flight path, respectively. The presence of a highly scattering/absorbing object (e.g., smoke plume and clouds) in either path, but not both, may increase the layer AOD derived by one method but not the other.

For example, the profile near the Camsell and Viking fires mentioned in Sect. 3.1.3 (Fig. 4b) showed AOD $_{499}$ (green circles) near 0 , rapidly increasing up to $>1$ near the bottom end of the profile with valid in situ data $(2200 \mathrm{~m})$. The AATS 
layer AOD calculated for $550 \mathrm{~nm}$ is 0.054 , and this value is used for Fig. 5. Depending on exactly which point we use as the very bottom of the AATS profile, this value varies by $>1$. The high sensitivity in this case makes the AATS-14 layer AOD prone to disagree with the in situ layer AOD.

The horizontal variability calls for caution in interpreting the in situ observation as well. The in situ layer AOD, identified to be 0.79 at $550 \mathrm{~nm}$, is less sensitive to the choice of the bottom point of the flight path than the AATS layer AOD. Most in-situ measurements are integrated into the layer AOD regardless. Nonetheless, the derived layer AOD could have been widely different for a marginally different flight path in and out of the smoke.

To indicate the AOD variability near the bottom end, we placed in Fig. $4 \mathrm{~b}$ a grey bar that encompasses the center $68 \%$ percentile of AATS AOD recorded within one minute of the bottom point, minus the AOD measured at the top of profile. Note that the $68 \%$ range does not capture the entire possible range of layer AOD. Rather, this range, equivalent to one standard deviation if the distribution were normal, represents the same confidence level as our instrument uncertainty estimates. This variable spans $0.0084-1.3$ at $550 \mathrm{~nm}$.

This measure of horizontal variability is shown in Fig. 5 for all vertical profiles. The two-minute time interval usually includes a horizontal leg near the bottom altitude and an ascent by up to $300 \mathrm{~m}$. We chose this length of time to capture an entire smoke plume, when present, while minimizing the portion of vertical gradient.

There are, however, caveats associated with this variability parameter. It does not capture the variability in aerosol loading under clouds, for which AATS data are either masked or, much less likely (Sect. 2.1), contaminated. An example is the 9 April 21:34-21:39 profile. At $2 \mathrm{~km}$ above the bottom of profile, the RH with regard to water reached $100 \%$, while that to ice exceeded $120 \%$. This humid layer brought the in-situ derived layer $\mathrm{AOD}_{550}$ to as high as 1.2. The AATS14 data were masked for this part of profile due to possible ice clouds. The AATS layer $\mathrm{AOD}_{550}$ derived from the top and bottom of profile is unaffected by the high humidity and is merely 0.034 . Variability above the bottom layer is not readily captured either. The data point for 6 July, 23:0123:11 is one example, with AATS-14 and in-situ derived layer $\mathrm{AOD}_{550}$ of 0.0075 and 0.20 , respectively. The large difference was caused by a highly scattering layer $500 \mathrm{~m}$ above the bottom of profile and below pyrocumulus clouds. Note also that the measure of variability itself becomes uncertain when the number of measurements within the \pm 1 min period is small.

The horizontal variability does explain most of the outliers. The profiles that do not fall within the $\pm(3 \%+0.02)$ bounds tend to have long variability bars, many stretching to the $1: 1$ line. All of those outliers with a $>0.1$ difference are associated with forest fire smoke plumes where aerosols were concentrated in a streak, commonly $<1-10 \mathrm{~km}$ wide. Thus, the layer AOD discrepancies evident in Fig. 5 do not mean poor instrument performance but aerosol horizontal or temporal variability-a limitation intrinsic to our AOD comparison methodology.

\subsubsection{Airborne and ground-based (AERONET) observations of full-column AOD spectra}

Generally, airborne and ground-based observations are conducted at different spatial (both vertical and horizontal) resolutions and different temporal resolutions, and can complement each other. In an effort to gain this benefit from the ARCTAS multi-platform arrangement, we examine the consistency between the AOD measurements made during five fly-over events.

Five profiles including the one near Monterey were flown over AERONET sites under clear skies. There was one more fly-over event but the AERONET level 1.5 and 2.0 AOD products for it are masked by the algorithm that looks at the temporal signal variability for cloud screening. For each of the five events we averaged the AERONET AOD observed during the profile, except for the flight over Pearl where the AERONET measurements made within $10 \mathrm{~min}$ before and after the aircraft profile were included in order to increase the number of data points from 0 to 6 .

To estimate total columnar AODs which would be comparable to the AERONET AODs, additions to the in-situ derived layer AOD were made to account for the light attenuation due to the additional atmosphere below and above the layer in which the aircraft flew. For the Monterey profile, the extinction at the bottom end of the profile is $34 \mathrm{Mm}^{-1}$ at $550 \mathrm{~nm}$. Under the assumption that the extinction between the aircraft and the Monterey AERONET site (50-70 m) was similar, the AOD contributed beneath the profile was 0.0007 , or $0.7 \%$ of the layer AOD. The AATS-14 average AOD at the top end of profile $(7400 \mathrm{~m}), 0.026$ at $550 \mathrm{~nm}$, was added as the AOD above the aircraft (with interpolations being carried out to the nephelometer wavelengths).

For both airborne estimates of full column AOD, these additional AODs were assumed to have a relative uncertainty of $100 \%$ independent of the layer AOD uncertainty. This treatment inflated the uncertainties by a factor of $\sim 1-3$. Figure 6 shows the AATS AOD both before (green markers) and after (blue) the adjustment for below-aircraft light attenuation. Because this adjustment is small, these markers often overlap with each other.

As shown in the middle of Fig. 6, the resulting full column AODs calculated for the Monterey profile agree within 0.02 , except at $440 \mathrm{~nm}$ (the difference is 0.04 ). This level of agreement seems excellent, especially since the AERONET measurement at 19:25:12 was 21 min after the AATS-14 bottom measurements (19:03:35-19:03:51) and the beginning of the in situ vertical profile (19:03:42-19:36:25). The P-3 aircraft penetrated the smoke layer about $2 \mathrm{~km}$ horizontally from the Monterey AERONET site, at 19:04:24. The smoke layer must have extended over this ground site; otherwise, 


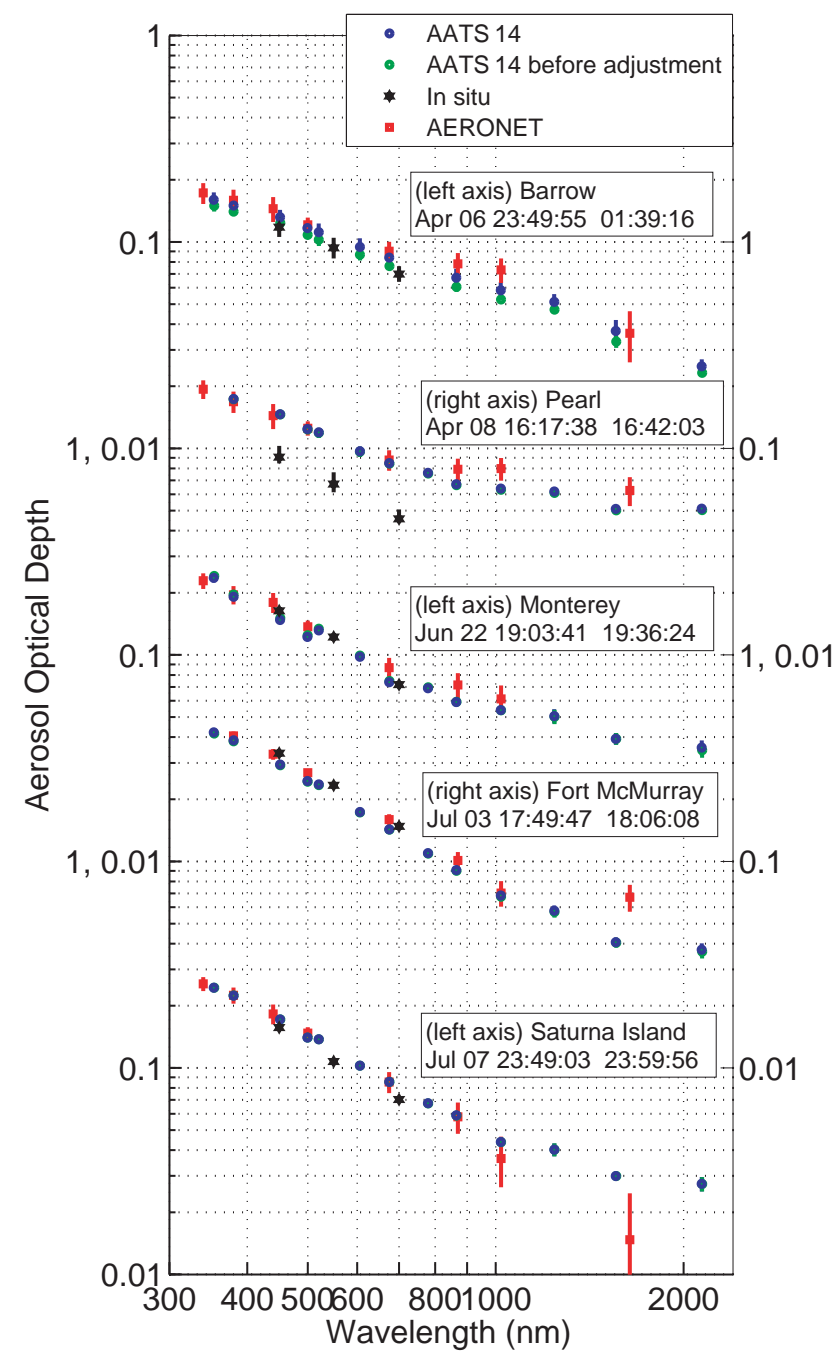

Fig. 6. Full-column AODs observed with airborne (AATS-14, $\mathrm{Neph}+\mathrm{PSAP}$ ) and ground-based (AERONET) instruments over Barrow, Pearl, Monterey, Fort McMurray and Saturna Island.

the AERONET and AATS would have recorded $\mathrm{AOD}_{499}$ closer to 0.05 , the value above the smoke. In fact, the 527$\mathrm{nm}$ micropulse lidar at the AERONET site also identified a sharp peak in extinction at 19:24:58, albeit with differences in its altitude (about $80 \mathrm{~m}$ higher) and magnitude $\left(350 \mathrm{Mm}^{-1}\right.$ compared to the in situ value of $\sim 500 \mathrm{Mm}^{-1}$ ) .

The AERONET and AATS AODs generally agreed within $\sim 0.02$ during the five fly-over events. Exceptions include the $1640 \mathrm{~nm}$ channel at Fort McMurray (the difference is 0.03). The column integral of the in-situ measurements agreed within $\sim 0.02$ with the AERONET 440, 500 and $675 \mathrm{~nm}$ measurements except for the Pearl profile. The AOD differences from the AATS measurements are given in Table 1.

Most likely a thin spider web or something in the channel's aperture that was later removed caused the Fort McMurray 1640-nm AOD to be too high at mid-day from mid May-mid August 2008. Airmass dependence suggestive of an artifactual (instrumental) transmission obstacle is apparent on some days. The 1640-nm channel has a different collimator from that used in the other channels. The calibration is not the cause of the anomalies. The AERONET 1640-nm filters are typically stable over an extended period of time. This was also the case for the instrument at Fort McMurray. The $1640 \mathrm{~nm}$ channel Vo coefficient (exoatmospheric detector voltage) only decreased by $\sim 1.5 \%$ over a 20 month time interval between calibrations. The AERONET Vo is linearly interpolated between pre- and post- deployment calibrations.

The profile over Pearl resulted in significant differences between the remote sensing and in situ measurements. The in situ data indicate that most of the layer AOD was contributed by an air mass as high as 4-7 km, unlike other profiles. The aircraft was $15-34 \mathrm{~km}$ away horizontally from the AERONET site during the profile through the $4-7 \mathrm{~km}$ altitude range. As it descended towards the lowest aircraft altitude where the AATS-14 AOD was recorded, it came slightly closer but still $14 \mathrm{~km}$ away from the site. It is possible that the aerosols at $4-7 \mathrm{~km}$ had a higher concentration along the AATS-14 and AERONET instrument's paths toward the Sun.

\subsection{Wavelength dependence and fine-mode fraction}

The general agreement between the airborne instruments and the AERONET (Sect. 3.2) makes it easier to relate our aircraft experiment to the continuous observations from the extensive ground network. As an example of such a link, the wavelength dependence and fine-mode fraction are each compared between the multiple observations in this section. As in the previous section, the comparison is made for the 55 vertical profiles selected from all phases of the campaign.

\subsubsection{Wavelength dependence}

We derive the wavelength dependence of AATS-14 AOD from a second-order polynomial fit (Sect. 3.1.1). Not surprisingly, given the typical small amount of curvature in a given AOD spectrum, this technique and the linear regression fit in $(\ln \lambda, \ln \mathrm{AOD})$ coordinates results in similar Ångström exponents over mid-visible wavelengths. The Ångström exponent from the linear fit over the five wavelengths between 453 and $675 \mathrm{~nm}$ is correlated with the second-order estimate at $519 \mathrm{~nm}$ as $1.03 \times A_{519}+0.01, R^{2}=0.84$, with a root mean square (RMS) difference of 0.20 for the ARCTAS AATS-14 data set. The linear fit over 453, 519 and $675 \mathrm{~nm}$ (approximating the TSI nephelometer wavelengths), $1.07 \times A_{519}-0.01$, results in a slightly lower $R^{2}(0.72)$ and higher RMS difference $(0.30)$. To give an idea of error introduced by extrapolation of AOD from the TSI nephelometer measurements, the layer AOD derived from the in situ measurements and extrapolated from the mid-visible wavelengths to $354 \mathrm{~nm}$ is within $\pm(25 \%+0.02)$ of the AATS-14 354-nm layer AOD for two thirds of the profiles with valid data. 
Table 1. Difference in optical properties during the AERONET fly-over events.

\begin{tabular}{|c|c|c|c|c|c|c|}
\hline \multirow[t]{2}{*}{ Place and date } & \multicolumn{3}{|c|}{ Difference, in situ-AATS } & \multicolumn{3}{|l|}{ Difference, AERONET-AATS } \\
\hline & $\mathrm{AOD}^{\mathrm{a}}$ & Ångström & SMF-FMF & $\mathrm{AOD}^{\mathrm{b}}$ & Ångström & FMF \\
\hline Barrow, 6 Apr 23:49:55-01:39:16 & $-0.01,-0.01,-0.01$ & 0.16 & 0.04 & $0.02,0.02,0.02,0.01,0.01,0.02,0.02,0.00$ & 0.16 & $-0,34$ \\
\hline Pearl, 8 Apr 16:17:38-16:42:04 & $-0.06,-0.04,-0.04$ & 0.72 & 0.24 & $0.02,-0.00,-0.01,0.00,0.00,0.01,0.02,0.01$ & 0,01 & -0.15 \\
\hline Monterey, 22 Jun 19:03:41-19:36:24 & $0.02,0.00,0.00$ & 0.39 & 0.14 & $-0.04,-0.00,0.02,0.01,0.01,0.01,0.01, \mathrm{NA}$ & 0.22 & -0.07 \\
\hline Fort McMurray, 3 Jul 17:49:47-18:06:08 & $0.04,0.02,0.01$ & 0.07 & 0.12 & NA, $0.02,0.02,0.03,0.02,0.01,0.00,0.03$ & -0.06 & -0.01 \\
\hline Saturna Island, 7 Jul 23:49:03-23:59:56 & $-0.02,-0.02,-0.01$ & 0.09 & 0.15 & $0.00,0.00,0.00,0.01,0.00,0.00,-0.01,-0.01$ & 0.11 & 0.00 \\
\hline
\end{tabular}

at 450, 550, 700 nm.

b At $340,380,440,500,675,870,1020,1640 \mathrm{~nm}$.

Figure 7a and b compare the Ångström exponents over mid-visible wavelengths between the integral (in situ) and differential (AATS-14) layer AODs. The Ångström exponent differences are $<0.31$ for two thirds of all cases. The agreement improves with increasing AOD. When $\mathrm{AOD}_{499}>0.1$, $89 \%$ of the cases fall within this category, and two thirds of the cases have an Ångström exponent difference $<0.13$. These statistics hold virtually the same for the profiles with the layer AOD discrepancies greater than $\pm(3 \%+0.02)$, indicated by the empty circles. This is consistent with the fact that the relative difference between the AATS and in situ layer AODs are more or less equal across all wavelengths (i.e., data points for the three wavelengths lie on a line nearly parallel to the 1:1 line for many outlier cases in Fig. 5). The Ångström exponents derived from AERONET full-column AOD spectra show deviations of similar magnitude (red squares).

A comparison of Ångström exponent was previously conducted between AATS-14 and satellite products off the US Northeast coast in 2004 (Russell et al., 2007). The ARCTAS data show about the same level of agreement. This is somewhat contrary to our expectation that the ARCTAS comparison between AATS-14 and in-situ estimates from layer measurements would be better than AATS-14 comparisons with retrievals from spaceborne measurements, since satellite measurements represent a spatial domain wider than the aircraft's and requires separation of surface reflectance.

\subsubsection{Fine-mode fraction}

In this section we compare the AOD FMF derived from the remote sensing measurements with the submicron fraction (SMF) measured in situ. These two parameters refer to different, albeit largely overlapping, size ranges. Therefore, we do not expect them to agree perfectly even under ideal conditions. However, comparing these two parameters is worthwhile, because it is one of the few conceivable ways to evaluate the remote sensing product against an in situ observation.

Submicron fraction was determined by the nephelometer and PSAP measurements behind a $1-\mu \mathrm{m}$ impactor, and adjusted to $500 \mathrm{~nm}$. The humidity response was assumed identical between submicron and total aerosols and at all midvisible wavelengths.

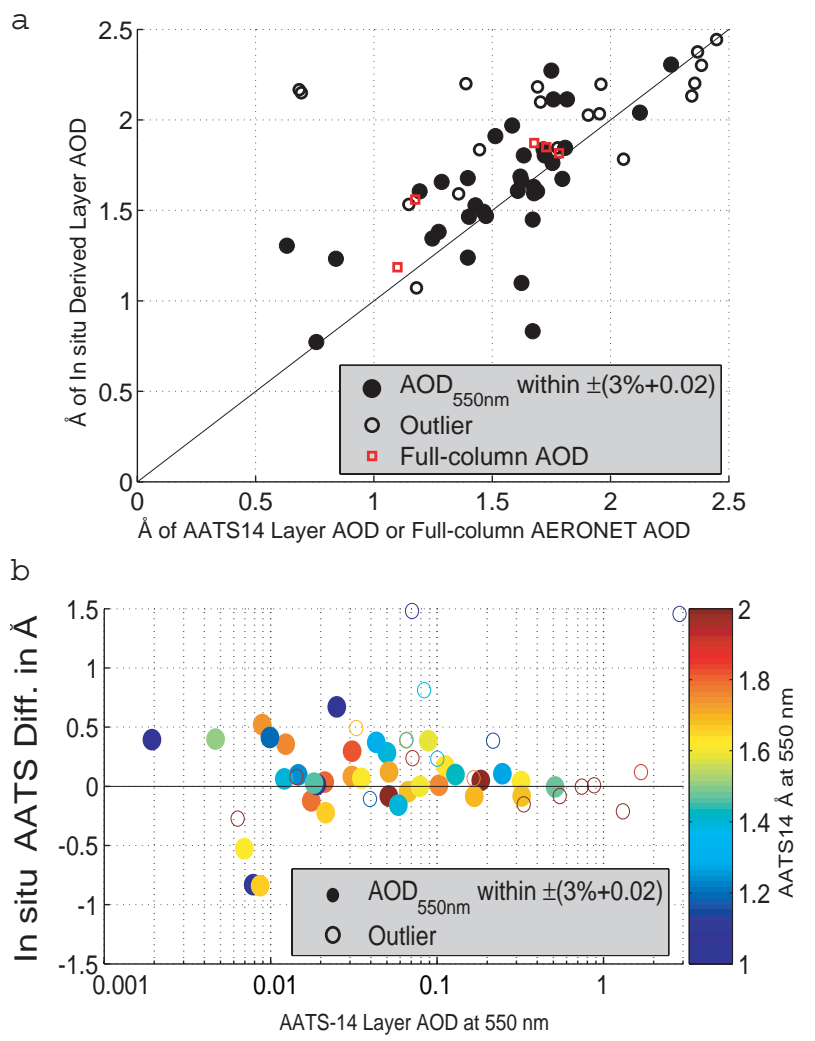

Fig. 7. (a) Ångström exponent of the layer AODs derived from the in situ instruments (determined via least square fit on log scales at 450, 550 and $700 \mathrm{~nm}, \mathrm{y}$-axis) and AATS-14 (the value at $550 \mathrm{~nm}$ of the second polynomial fit, $\mathrm{x}$-axis). The filled markers indicate the vertical profiles that see agreement within $3 \%+0.02$ between the layer AODs. Other profiles are marked with empty circles. The red squares compare the 440/675 nm Ångström exponent of fullcolumn AERONET AOD with the in situ Ångström exponent for the AERONET fly-over cases. (b) The difference in the in-situ and AATS-14 Ångström exponents, compared against the AATS14 layer $\mathrm{AOD}_{550}$.

The AATS-14 and AERONET results were derived from O'Neill et al.'s (2001, 2003, 2008a) algorithm that translates the spectral curvature between 380 and $870 \mathrm{~nm}$ into estimates of FMF. AERONET Level 2.0 retrievals from the inversion scheme developed by Dubovik and King (2000) and Dubovik et al. (2000) are not available for the five AERONET fly-over 

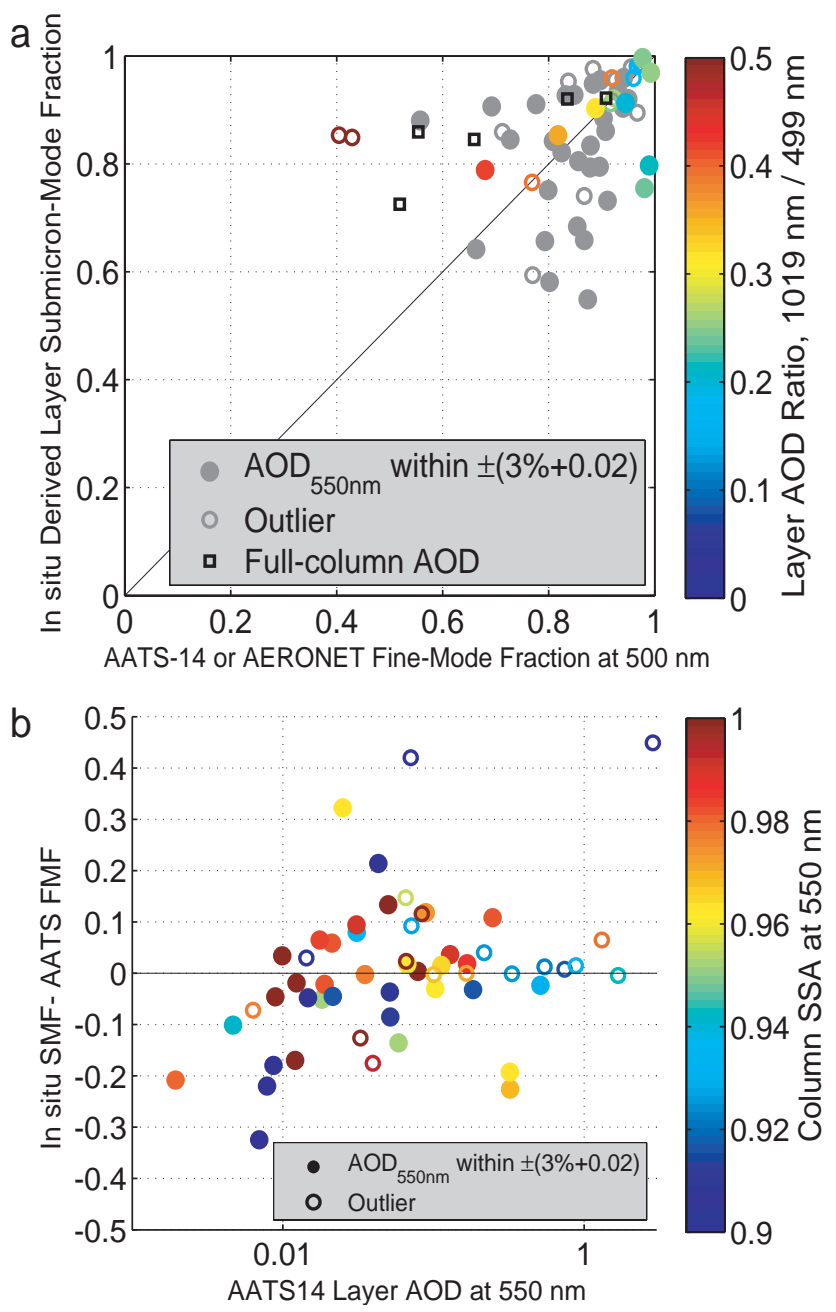

Fig. 8. (a) Fine-mode fraction of AATS-14 (circle) layer AOD and AERONET full-column AOD (black square) individually compared with the submicron-mode fraction of in situ derived layer AOD adjusted to $500 \mathrm{~nm}$ (vertical axis). The filled markers indicate the vertical profiles that see agreement within $3 \%+0.02$ between the layer AODs. Other profiles are marked with empty circles. The color indicates the 1019/499 AOD ratio, for data with 1019 nm AODs greater than 0.04. (b) The difference between SMF and AATS-14 FMF, plotted against the AATS layer AOD interpolated to $550 \mathrm{~nm}$. The marker color indicates column-integrated SSA.

events. The AERONET data represent the whole column, whereas the two airborne data sets represent the layer in which the aircraft flew.

These variables are compared in Fig. 8a. Both FMF and SMF values lie between 0.8 and 1.0 for most profiles. The root square mean of their difference is 0.13 for the 36 profiles with good layer $\mathrm{AOD}_{550}$ agreement (within $3 \%+0.02$; see Fig. 5) and 0.14 for all 55 profiles. The FMF derived from AERONET full-column AOD spectra (squares in Fig. 8a) show a similar point dispersion to the layer AOD results.
Figure $8 \mathrm{~b}$ shows the SMF-FMF difference versus the AATS layer AOD (interpolated to $550 \mathrm{~nm}$ ) and color-coded with the column-integrated SSA. A slight bias towards higher SMF might exist for those among the 36 profiles (filled marker) with high SSA. It is noted that the retrievals of FMF decrease in accuracy with decreasing AOD.

The in situ SMF is within $\pm 5 \%$ of the AATS FMF for two thirds of the 19 profiles with $1019 \mathrm{~nm}$ layer AOD $>0.04$, a criterion employed by Gasso and O'Neill (2006). This margin is smaller than the 5-15\% that Gasso and O'Neill (2006) find for ACE-Asia data with high (>0.5) FMF. The authors point out that in ACE-Asia the differences tend to decrease as FMF approaches 1. This trend is not evident in our ARCTAS data.

Previous studies in East Asia (Anderson et al., 2005) and Mexico (Redemann et al., 2009b) fit a second-order function of in situ extinction Angstroom exponent to in situ derived SMF, in an attempt to translate column AOD into SMF. The functions, if applied to the ARCTAS column-integral results presented here, underestimate SMF by $0-0.2$. This is shown in the Supplement (Fig. S2).

Because of their sensitivity to coarse particles, AODs at near-infrared wavelengths might better constrain FMF. As a quick test for this hypothesis, we attempted to stratify the FMF-SMF relationship with AATS AODs beyond $870 \mathrm{~nm}$. One example of such attempts is shown with the marker color of Fig. 8a which indicates the ratio of AATS 1019-nm AOD to the 499-nm. Data with 1019-nm AOD under 0.04 are masked with grey color. We find consistent trends between this ratio and the FMF, the latter derived from AODs up to $865 \mathrm{~nm}$ : Finer particles exhibit higher wavelength dependence (lower 1019/499 AOD ratio). However consistent it may be, the use of $1019 \mathrm{~nm}$, or longer wavelengths for that matter, appears to provide little additional constraint, at least when FMF is evaluated against SMF. We note that O'Neill et al. (2008b) did demonstrate that the slope of the coarse mode optical depth at $1640 \mathrm{~nm}$ was sensitive to the effective radius of coarse mode particles.

\section{Conclusions}

AOD was measured with the AATS-14 from the NASA P-3 aircraft at the northern high latitudes of Alaska and Canada as well as in California during the ARCTAS experiment. We have discussed the vertical profiles, inter-comparison with correlative observations, and fine-mode fraction.

The vertical profiles of AOD and in situ aerosol properties we observed over Alaska in April 2008 corroborates the hypothesis that Arctic haze, a term frequently used for relatively high extinction over this region, may refer to particles from either biomass burning or anthropogenic emissions, partly depending on the altitude (Sect. 3.1). The AOD Ångström exponent was $1.4 \pm 0.3$ up to $2 \mathrm{~km}$, which is somewhat smaller than the values of $1.7 \pm 0.1$ between $2-4 \mathrm{~km}$. 
Sulfate dominated the boundary layer, possibly owing to anthropogenic emissions at northern mid-latitudes. Carbonaceous material was pronounced in the lower free troposphere, possibly owing to Siberian forest fires.

The inter-comparison of multiple AOD measurements during vertical profiles reveals high consistency among them, except in the presence of high horizontal variability (Sect. 3.2). The layer AOD derived from AATS-14 airborne remote sensing agrees with the vertical integral of in situ nephelometer scattering and PSAP absorption coefficients within $3 \%+0.02$ for two thirds of the 55 vertical profiles examined. Almost all outliers were associated with high horizontal variability caused by forest fire smoke over central Canada in June and July 2008. Anomalies of this nature do not mean poor instrument performance but a limitation intrinsic to our AOD comparison methodology. These two types of airborne AOD measurements, after compensation for below-aircraft light attenuation by vertical extrapolation, typically fell within 0.02 of AERONET ground-based measurements for five overpass events.

FMF was retrieved from the spectral curvature of AATS14 AOD and compared with the column-integrated, in situ derived SMF (Sect. 3.3). The FMF was between 0.8 and 1.0 for most of the vertical profiles. The SMF, measured with a 1- $\mu \mathrm{m}$ impactor, differed from the FMF by $0.13 \mathrm{RMS}$ for the profiles with the good $(3 \%+0.02)$ layer AOD agreement. SMF and FMF are defined for slightly different size ranges and are not expected to be identical. Nonetheless, this comparison is meaningful as it is one of the few conceivable ways to evaluate the remote sensing product. The Ångström exponent over mid-visible wavelengths was also compared. The differences were $<0.31$ for two thirds of all profiles, and $<0.13$ for two thirds of those with $\mathrm{AOD}_{499}$ greater than 0.1.

\section{Supplementary material related to this article is available online at: http://www.atmos-chem-phys.net/11/3673/2011/ acp-11-3673-2011-supplement.pdf.}

Acknowledgements. We are particularly grateful to the support crews of the NASA P-3. We would also like to thank Jim Podolske, Jeff Reid, Tom Eck, Ihab Abboud, Lorraine Remer and Rich Kleidman for their input, and the AERONET and AEROCAN teams for maintaining the field instruments and processing the AERONET data. Yohei Shinozuka was partially supported by an appointment to the NASA Postdoctoral Program at the Ames Research Center, administered by Oak Ridge Associated Universities through a contract with NASA. AATS-14 observations were funded by NASA grant NNX08AF88G.

Edited by: P. Monks

\section{References}

Allan, J. D., Coe, H., Bower, K. N., Alfarra, M. R., Delia, A. E., Jimenez, J. L., Middlebrook, A. M., Drewnick, F., Onasch, T. B., Canagaratna, M. R., Jayne, J. T., and Worsnop, D. R.: Technical Note: Extraction of Chemically Resolved Mass Spectra from Aerodyne Aerosol Mass Spectrometer Data, J. Aerosol Sci., 35, 909-922, 2004.

Anderson, T. L. and Ogren, J. A.: Determining aerosol radiative properties using the TSI 3563 integrating nephelometer, Aerosol Sci. Technol., 29, 57-69, 1998.

Anderson, T. L., Covert, D. S., Marshall, S. F., Laucks, M. L., Charlson, R. J., Waggoner, A. P., Ogren, J. A., Caldow, R., Holm, R. L., Quant, F. R., Sem, G. J., Wiedensohler, A., Ahlquist, N. A., and Bates, T. S.: Performance characteristics of a high-sensitivity, three-wavelength, total scatter/backscatter nephelometer, J. Atmos. Ocean. Tech., 13, 967-986, 1996.

Anderson, T. L., Charlson, R. J., Winker, D. M., Ogren, J. A., and Holmen, K.: Mesoscale variations of tropospheric aerosols, J. Atmos. Sci., 60, 119-136, 2003.

Anderson, T. L., Wu, Y. H., Chu, D. A., Schmid, B., Redemann, J., and Dubovik, O.: Testing the MODIS satellite retrieval of aerosol fine-mode fraction, J. Geophys. Res.-Atmos., 110, D18204, doi:10.1029/2005JD005978, 2005.

Campbell, J. R., Hlavka, D. L., Welton, E. J., Flynn, C. J., Turner, D. D., Spinhirne, J. D., Scott, V. S., and Hwang, I. H.: Fulltime, Eye-Safe Cloud and Aerosol Lidar Observation at Atmospheric Radiation Measurement Program Sites: Instrument and Data Processing, J. Atmos. Oceanic Tech., 19, 431-442, 2002.

Canagaratna, M. R., Jayne, J. T., Jimenez, J. L., Allan, J. D., Alfarra, M. R., Zhang, Q., Onasch, T. B., Drewnick, F., Coe, H., Middlebrook, A., Delia, A., Williams, L. R., Trimborn, A. M., Northway, M. J., DeCarlo, P. F., Kolb, C. E., Davidovits, P., and Worsnop, D. R.: Chemical and Microphysical Characterization of Ambient Aerosols with the Aerodyne Aerosol Mass Spectrometer, Mass Spectrom. Rev., 26, 185-22, 2007.

Chu, D. A., Remer, L. A., Kaufman, Y. J., Schmid, B., Redemann, J., Knobelspiesse, K., Chern, J.-D., Livingston, J., Russell, P. B., Xiong, X., and Ridgway, W.: Evaluation of aerosol properties over ocean from Moderate Resolution Imaging Spectroradiometer (MODIS) during ACE-Asia, J. Geophys. Res., 110, D07308, doi:07310.01029/02004JD005208, 2005.

Clarke, A. D., Varner, J. L., Eisele, F., Mauldin, R. L., Tanner, D., and Litchy, M.: Particle production in the remote marine atmosphere: Cloud outflow and subsidence during ACE 1, J. Geophys. Res., 103, 16397-316409, 1998.

DeCarlo, P. F., Kimmel, J. R., Trimborn, A., Northway, M. J., Jayne, J. T., Aiken, A. C., Gonin, M., Fuhrer, K., Horvath, T., Docherty, K., Worsnop, D. R., and Jimenez, J. L.: Field-Deployable, HighResolution, Time-of-Flight Aerosol Mass Spectrometer, Anal Chem., 78, 8281-8289, 2006.

Dubovik, O. and King, M. D.: A flexible inversion algorithm for retrieval of aerosol optical properties from Sun and sky radiance measurements, J. Geophys. Res., 105, 20673-20696, 2000.

Dubovik, O., Smirnov, A., Holben, B. N., King, M. D., Kaufman, Y. J., Eck T. F., and Slutsker, I.: Accuracy assessment of aerosol optical properties retrieval from AERONET sun and sky radiance measurements, J. Geophys. Res., 105, 9791-9806, 2000.

Dubovik, O., Holben, B., Eck, T. F., Smirnov, A., Kaufman, Y. J., King, M. D., Tanre, D., and Slutsker, I.: Variability of absorption 
and optical properties of key aerosol types observed in worldwide locations, J. Atmos. Sci., 59, 590-608, 2002.

Eck, T. F., Holben, B. N., Reid, J. S., Dubovik, O., Smirnov, A., O’Neill, N. T. O., Slutsker, I., and Kinne, S.: Wavelength dependence of the optical depth of biomass burning, urban, and desert dust aerosols, J. Geophys. Res., 104, 31333-31349, 1999.

Eck, T. F., Holben, B. N., Dubovik, O., Smirnov, A., Slutsker, I., Lobert, J. M., and Ramanathan, V.: Column-integrated aerosol optical properties over the Maldives during the northeast monsoon for 1998\&\#8211;2000, J. Geophys. Res., 106, 2855528566, 2001.

Fuelberg, H. E., Harrigan, D. L., and Sessions, W.: A meteorological overview of the ARCTAS 2008 mission, Atmos. Chem. Phys., 10, 817-842, doi:10.5194/acp-10-817-2010, 2010.

Ferek, R. J., Hobbs, P. V., Radke, L. F., Herring, J. A., Sturges, W. T., and Cota, G. F.: Dimethyl sulfide in the arctic atmosphere, J. Geophys. Res., 100, 26093-26104, 1995.

Garrett, T. J., Hobbs, P. V., and Radke, L. F.: High Aitken Nucleus Concentrations above Cloud Tops in the Arctic, J. Atmos.Sci. , 59, 779-783, 2002.

Garrett, T. J., Zhao, C., Dong, X., Mace, G. G., and Hobbs, P. V.: Effects of varying aerosol regimes on low-level Arctic stratus, Geophys. Res. Lett., 31, L17105, doi:10.1029/2004GL019928, 2004.

Gassó, S.,and Hegg, D. A.: On the retrieval of columnar aerosol mass and CCN concentration by MODIS, J. Geophys. Res.Atmos., 108, 4010, doi:10.1029/2002JD002382, 2003.

Gassó, S. and O'Neill, N.: Comparisons of remote sensing retrievals and in situ measurements of aerosol fine mode fraction during ACE-Asia, Geophys. Res. Lett., 33, L05807, doi:10.1029/2005GL024926, 2006.

Holben, B. N., Eck, T. F., Slutsker, I., Tanre, D., Buis, J. P., Setzer, A., Vermote, E., Reagan, J. A., Kaufman, Y. J., Nakajima, T., Lavenu, F., Jankowiak, I., and Smirnov, A.: AERONET - A federated instrument network and data archive for aerosol characterization, Remote Sens. Environ., 66, 1-16, 1998.

Holben, B. N., Tanré, D., Smirnov, A., Eck, T. F., Slutsker, I., Abuhassan, N., Newcomb, W. W., Schafer, J. S., Chatenet, B., Lavenu, F., Kaufman, Y. J., Castle, J. V., Setzer, A., Markham, B., Clark, D., Frouin, R., Halthore, R., Karneli, A., O'Neill, N. T., Pietras, C., Pinker, R. T., Voss, K., and Zibordi, G.: An emerging ground-based aerosol climatology: Aerosol optical depth from AERONET, J. Geophys. Res., 106, 12067-12097, 2001.

Jacob, D. J., Crawford, J. H., Maring, H., Clarke, A. D., Dibb, J. E., Emmons, L. K., Ferrare, R. A., Hostetler, C. A., Russell, P. B., Singh, H. B., Thompson, A. M., Shaw, G. E., McCauley, E., Pederson, J. R., and Fisher, J. A.: The Arctic Research of the Composition of the Troposphere from Aircraft and Satellites (ARCTAS) mission: design, execution, and first results, Atmos. Chem. Phys., 10, 5191-5212, doi:10.5194/acp-10-5191-2010, 2010.

Jethva, H., Satheesh, S. K., and Srinivasan, J.: Seasonal variability of aerosols over the Indo-Gangetic basin, J. Geophys. Res., 110, D21204, doi:10.1029/2005JD005938, 2005.

Jethva, H., Satheesh, S. K., and Srinivasan, J.: Evaluation of Moderate-Resolution Imaging Spectroradiometer (MODIS) Collection 004 (C004) aerosol retrievals at Kanpur, Indo-Gangetic Basin, J. Geophys. Res., 112, D14216, doi:10.1029/2006JD007929, 2007.

Kaufman, Y., Tanré, D., and Boucher, O.: A satellite view of aerosols in the climate system, Nature, 419, 215-223, 2002.

Kleidman, R. G., O’Neill, N. T., Remer, L. A., Kaufman, Y. J., Eck, T. F., Tanré, D., Dubovik, O., and Holben, B. N.: Comparison of Moderate Resolution Imaging Spectroradiometer (MODIS) and Aerosol Robotic Network (AERONET) remote-sensing retrievals of aerosol fine mode fraction over ocean, J. Geophys. Res., 110, doi:10.1029/2005JD005760, 2005.

Levy, R. C., Remer, L. A., Tanré, D., Kaufman, Y. J., Ichoku, C., Holben, B. N., Livingston, J. M., Russell, P. B., and Maring, H. B.: Evaluation of the Moderate-Resolution Imaging Spectroradiometer (MODIS) retrievals of dust aerosol over the ocean during PRIDE, J. Geophys. Res., 108, 8594, doi:8510.1029/2002JD002460, 2003.

Levy, R.C., L.A. Remer, J.V. Martins, Y.J. Kaufman, A. PlanaFattori, J. Redemann, B. Wenny, Evaluation of the MODIS aerosol retrievals over ocean and land during CLAMS, J. Atmos. Sci., 62(4), 974-992, 2005.

Livingston, J. M., Russell, P. B., Reid, J. S., Redemann, J., Schmid, B., Allen, D. A., Torres, O., Levy, R. C., Remer, L. A., Holben, B. N., Smirnov, A., Dubovik, O., Welton, E. J., Campbell, J. R., Wang, J., and Christopher, S. A.: Airborne Sun photometer measurements of aerosol optical depth and columnar water vapor during the Puerto Rico Dust Experiment and comparison with land, aircraft, and satellite measurements, J. Geophys. Res., 108, 8588, doi:8510.1029/2002JD002520, 2003.

Livingston, J. M., Schmid, B., Russell, P. B., Eilers, J. A., Kolyer, R. W., Redemann, J., Ramirez, S. R., Yee, J.-H., Swartz, W. H., Trepte, C. R., Thomason, L. W., Pitts, M. C., Avery, M. A., Randall, C. E., Lumpe, J. D., Bevilacqua, R. M., Bittner, M., Erbertseder, T., McPeters, R. D., Shetter, R. E., Browell, E. V., Kerr, J. B., and Lamb, K.: Retrieval of ozone column content from airborne Sun photometer measurements during SOLVE II: comparison with coincident satellite and aircraft measurements, Atmos. Chem. Phys., 5, 2035-2054, doi:10.5194/acp-5-2035-2005, 2005.

Livingston, J. M., Schmid, B., Redemann, J., Russell, P. B., Ramirez, S. A., Eilers, J., Gore, W., Howard, S., Pommier, J., Fetzer, E. J., Seemann, S. W., Borbas, E., Wolfe, D. E., and Thompson, A. M., Comparison of water vapor measurements by airborne Sun photometer and near-coincident in situ and satellite sensors during INTEX/ITCT 2004, J. Geophys. Res., 112, D12S16, doi:10.1029/2006JD007733, 2007.

Livingston, J. M., Redemann, J., Russell, P. B., Torres, O., Veihelmann, B., Veefkind, P., Braak, R., Smirnov, A., Remer, L., Bergstrom, R. W., Coddington, O., Schmidt, K. S., Pilewskie, P., Johnson, R., and Zhang, Q.: Comparison of aerosol optical depths from the Ozone Monitoring Instrument (OMI) on Aura with results from airborne sunphotometry, other space and ground measurements during MILAGRO/INTEX-B, Atmos. Chem. Phys., 9, 6743-6765, doi:10.5194/acp-9-6743-2009, 2009.

Matsumoto, T., Russell, P., Mina, C., Van Ark, W., and Banta, V.: Airborne Tracking Sunphotometer, J. Atmos. Ocean. Tech., 4, 336-339, 1987.

McNaughton, C. S., Clarke, A. D., Kapustin, V., Shinozuka, Y., Howell, S. G., Anderson, B. E., Winstead, E., Dibb, J., Scheuer, E., Cohen, R. C., Wooldridge, P., Perring, A., Huey, L. G., Kim, S., Jimenez, J. L., Dunlea, E. J., DeCarlo, P. F., Wennberg, P. O., Crounse, J. D., Weinheimer, A. J., and Flocke, F.: Obser- 
vations of heterogeneous reactions between Asian pollution and mineral dust over the Eastern North Pacific during INTEX-B, Atmos. Chem. Phys., 9, 8283-8308, doi:10.5194/acp-9-8283-2009, 2009.

McNaughton, C. S., Clarke, A. D., Freitag, S., Kapustin, V. N., Kondo, Y., Moteki, N., Sahu, L., Takegawa, N., Schwarz, J. P., Spackman, J. R., Watts, L., Diskin, G., Podolske, J., Holloway, J. S., Wisthaler, A., Mikoviny, T., de Gouw, J., Warneke, C., Jimenez, J., Cubison, M., Howell, S. G., Middlebrook, A., Bahreini, R., Anderson, B. E., Winstead, E., Thornhill, K. L., Lack, D., Cozic, J., and Brock, C. A.: Absorbing aerosol in the troposphere of the Western Arctic during the 2008 ARCTAS/ARCPAC airborne field campaigns, Atmos. Chem. Phys. Discuss., 11, 1543-1594, doi:10.5194/acpd-111543-2011, 2011.

O’Neill, N. T., Dubovik, O., and Eck, T. F.: Modified Ångström exponent for the characterization of submicrometer aerosols, Appl. Optics, 40, 2368-2375, 2001.

O’Neill, N. T., Eck, T. F., Smirnov, A., Holben, B. N., and Thulasiraman, S.: Spectral discrimination of coarse and fine mode optical depth, J. Geophys. Res., 108, 4559, doi:4510.1029/2002JD002975, 2003.

O’Neill, N. T., Eck, T. F., Smirnov, A., Holben B. N., S. Thulasiraman, Spectral Deconvolution algorithm Technical memo, 2008a.

O’Neill, N. T., Eck, T. F., Reid, J. S., Smirnov, A., and Pancrati, O.: Coarse mode optical information retrievable using ultraviolet to shortwave infrared sunphotometry; application to $\mathrm{UAE}^{2}$, J. Geophys. Res., 113, D05212, doi:10.1029/2007JD009052, 2008b.

Radke, L. F., Hobbs, P. V., and Bailey, I. H.: Airborne observations of Arctic aerosols. III: Origins and effects of airmasses, Geophys. Res. Lett., 11(5), 401-404, doi:10.1029/GL011i005p00401, 1984.

Ramachandran, S.: Aerosol optical depth and fine mode fraction variations deduced from Moderate Resolution Imaging Spectroradiometer (MODIS) over four urban areas in India, J. Geophys. Res., 112, D16207, doi:16210.11029/12007JD008500, 2007.

Redemann, J., Masonis, S. J., Schmid, B., Anderson, T. L., Russell, P. B., Livingston, J. M., Dubovik, O., and Clarke, A. D.: Clearcolumn closure studies of aerosols and water vapor aboard the NCAR C-130 during ACE-Asia, 2001, J. Geophys. Res., 108, 8655, doi:8610.1029/2003JD003442, 2003.

Redemann, J., Schmid, B., Eilers, J. A., Kahn, R., Levy, R. C., Russell, P. B., Livingston, J. M., Hobbs, P. V., Smith, W. L., and Holben, B. N.: Suborbital measurements of spectral aerosol optical depth and its variability at subsatellite grid scales in support of CLAMS 2001, J. Atmos. Sci., 62, 993-1007, 2005.

Redemann, J., Zhang, Q., Schmid, B., Russell, P. B., Livingston, J. M., Jonsson, H., and Remer, L. A.: Assessment of MODIS-derived visible and near-IR aerosol optical properties and their spatial variability in the presence of mineral dust, Geophysical Research Letters, 33, L18814, doi:18810.11029/12006GL026626, 2006.

Redemann, J., Shinozuka, Y., Livingston, J., Russell, P., Pilewskie, P., Schmidt, S., Bierwirth, E., Johnson, R., Clarke, A., Howell, S., McNaughton, C., Freitag, S., Remer, L., Mattoo, S., Torres, O., Veefkind, P., Ferrare, R., Hostetler, C., Hair, J., Cairns, B., Knobelspiesse, K., Ottaviani, M., and Bucholtz, A.: The coordinated multi-sensor, multi-platform ARCTAS fire plume study on 30 June 2008, Eos Trans. AGU, 90(52), Fall Meet. Suppl.,
Abstract 719884, 2009.

Redemann, J., Zhang, Q., Russell, P. B., Livingston, J. M., and Remer, L. A.: Case studies of aerosol remote sensing in the vicinity of clouds, J. Geophys. Res., 114, D06209, doi:06210.01029/02008JD010774, 2009a.

Redemann, J., Zhang, Q., Livingston, J., Russell, P., Shinozuka, Y., Clarke, A., Johnson, R., and Levy, R.: Testing aerosol properties in MODIS Collection 4 and 5 using airborne sunphotometer observations in INTEX-B/MILAGRO, Atmos. Chem. Phys., 9, 8159-8172, doi:10.5194/acp-9-8159-2009, 2009 b.

Russell, P. B., Livingston, J. M., Dutton, E. G., Pueschel, R. F., Reagan, J. A., DeFoor, T. E., Box, M. A., Allen, D., Pilewskie, P., Herman, B. M., Kinne, S. A., and Hofmann, D. J.: Pinatubo And Pre-Pinatubo Optical Depth Spectra: Mauna Loa Measurements, Comparisons, Inferred Particle Size Distributions, Radiative Effects, And Relationship To Lidar Data, J. Geophys. Res., 98, 22969-22985, 1993a.

Russell, P. B., Livingston, J. M., Pueschel, R. F., Reagan, J. A., Browell, E. V., Toon, G. C., Newman, P. A., Schoeberl, M. R., Lait, L. R., Pfister, L., Gao, Q., and Herman, B. M.: PostPinatubo optical depth spectra vs. latitude and vortex structure: Airborne tracking sunphotometer measurements in AASE II, Geophys. Res. Lett., 20, 2571-2574, 1993b.

Russell, P. B., Livingston, J. M., Hignett, P., Kinne, S., Wong, J., and Hobbs, P. V.: Aerosol-induced radiative flux changes off the United States Mid-Atlantic coast, Comparison of values calculated from sunphotometer and in situ data with those measured by airborne pyranometer, J. Geophys. Res., 104, 2289-2307, 1999.

Russell, P. B., Livingston, J. M., Dubovik, O., Ramirez, S. A., Wang, J., Redemann, J., Schmid, B., Box, M., and Holben, B. N.: Sunlight transmission through desert dust and marine aerosols: Diffuse light corrections to Sun photometry and pyrheliometry, J. Geophys. Res., 109, D08207, doi:10.1029/2003JD004292, 2004.

Russell, P., Livingston, J., Schmid, B., Eilers, J., Kolyer, R., Redemann, J., Ramirez, S., Yee, J.-H., Swartz, W., Shetter, R., Trepte, C., Risley Jr., A., Wenny, B., Zawodny, J., Chu, W., Pitts, M., Lumpe, J., Fromm, M., Randall, C., Hoppel, K., and Bevilacqua, R.: Aerosol optical depth measurements by airborne sun photometer in SOLVE II: Comparisons to SAGE III, POAM III and airborne spectrometer measurements, Atmos. Chem. Phys., 5, 1311-1339, doi:10.5194/acp-5-1311-2005, 2005.

Russell, P. B., Livingston, J. M., Redemann, J., Schmid, B., Ramirez, S. A., Eilers, J., Khan, R., Chu, A., Remer, L., Quinn, P. K., Rood, M. J., and Wang, W.: Multi-GridCell Validation of Satellite Aerosol Property Retrievals in INTEX/ITCT/ICARTT 2004, J. Geophys. Res., 112, D12S09, doi:10.1029/2006JD007606, 2007.

Russell, P. B., Bergstrom, R. W., Shinozuka, Y., Clarke, A. D., DeCarlo, P. F., Jimenez, J. L., Livingston, J. M., Redemann, J., Dubovik, O., and Strawa, A.: Absorption Angstrom Exponent in AERONET and related data as an indicator of aerosol composition, Atmos. Chem. Phys., 10, 1155-1169, doi:10.5194/acp10-1155-2010, 2010.

Saha, A., O’Neill, N. T., Eloranta, E., Stone, R. S., Eck, T. F., Zidane, S., Daou, D., Lupu, A., Lesins, G., Shiobara, M., and McArthur, L. J. B.: Pan-Arctic sunphotometry during the ARCTAS-A campaign of April 2008, Geophys. Res. Lett., 37, L05803, doi:05810.01029/02009GL041375, 2010. 
Scheuer, E., Talbot, R. W., Dibb, J. E., Seid, G. K., DeBell, L., and Lefer, B.: Seasonal distributions of fine aerosol sulfate in the North American Arctic basin during TOPSE, J. Geophys. Res., 108(D4), 8370, doi:10.1029/2001JD001364, 2003.

Schmid, B. and Wehrli, C.: Comparison of sun photometer calibration by Langley technique and standard lamp, Appl. Optics, 34, 4500-4512, 1995.

Schmid, B., Thome, K. J., Demoulin, P., Peter, R., Mätzler, C., and Sekler, J.: Comparison of Modeled and Empirical Approaches for Retrieving Columnar Water Vapor from Solar Transmittance Measurements in the 0.94 Micron Region. J. Geophys. Res., 101 (D5), 9345-,9358, 1996.

Schmid, B., Spyak, P. R., Biggar, S. F., Wehrli, C., Sekler, J., Ingold, T., Mätzler, C., and Nämpfer, K.: Evaluation of the applicability of solar and lamp radiometric calibrations of a precision Sun photometer operating between 300 and $1025 \mathrm{~nm}$. Appl. Optics, 37(18), 3923-3941, 1998.

Schmid, B., J. J., Michalsky, D. W., Slater, J. C., Barnard, R. N., Halthore, J. C., Liljegren, B. N., Holben, T. F., Eck, J. M., Livingston, P. B., Russell, T., Ingold, and I. Slutsker, : Comparison of columnar water-vapor measurements from solar transmittance methods, Appl. Optics, 40(12), 1886-1896, 2001.

Schmid, B., Hegg, D. A., Wang, J., Bates, D., Redemann, J., Russell, P. B., Livingston, J. M., Jonsson, H. H., Welton, E. J., Seinfeld, J. H., Flagan, R. C., Covert, D. S., Dubovik, O., and Jefferson, A.: Column closure studies of lower tropospheric aerosol and water vapor during ACE-Asia using airborne Sun photometer and airborne in situ and ship-based lidar measurements, J. Geophys. Res., 108, 8656, doi:10.1029/2002JD003361, 2003a.

Schmid, B., Redemann, J., Russell P. B., Hobbs, P. V., Hlavka, D. L., McGill, M. J., Holben, B. N., Welton, E. J., Campbell, J. R., Torres, O., Kahn, R. A., Diner, D. J., Helmlinger, M. C., Chu, D. A., Robles-Gonzalez, C., and de Leeuw, G., Coordinated airborne, spaceborne, and ground-based measurements of massive, thick aerosol layers during the dry season in Southern Africa, J. Geophys. Res., 108 (D13), 8496, doi:10.1029/2002JD002297, 2003b.
Smirnov, A., Holben, B. N., Eck, T. F., Dubovik, O., and Slutsker, I.: Cloud screening and quality control algorithms for the AERONET database, Remote Sens. Environ., 73, 337-349, 2000.

Stephens, M., Turner, N., and Sandberg, J.: Particle Identification by Laser-Induced Incandescence in a Solid-State Laser Cavity, Appl. Optics, 42, 3726-3736, 2003.

Stone, R. S., Herber, A., Vitale, V., Mazzola, M., Lupi, A., Schnell, R. C., Dutton, E. G., Liu, P. S. K., Li, S. M., Dethloff, K., Lampert, A., Ritter, C., Stock, M., Neuber, R., and Maturilli, M.: A three-dimensional characterization of Arctic aerosols from airborne Sun photometer observations: PAM-ARCMIP, April 2009, J. Geophys. Res., 115, D13203, doi:13210.11029/12009JD013605, 2010.

Virkkula, A.: Correction of the Calibration of the 3-wavelength Particle Soot Absorption Photometer ( $3 \lambda$ PSAP), Aerosol Sci. Technol., 44, 706-712, 2010.

Virkkula, A., Ahlquist, N. C., Covert, D. S., Arnott, W. P., Sheridan, P. J., Quinn, P. K., and Coffman, D. J.: Modification, Calibration and a Field Test of an Instrument for Measuring Light Absorption by Particles, Aerosol Sci. Technol., 39, 68-83, 2005.

Warneke, C., Froyd, K. D., Brioude, J., Bahreini, R., Brock, C. A., Cozic, J., de Gouw, J. A., Fahey, D. W., Ferrare, R., Holloway, J. S., Middlebrook, A. M., Miller, L., Montzka, S., Schwarz, J. P., Sodemann, H., Spackman, J. R., and Stohl, A.: An important contribution to springtime Arctic aerosol from biomass burning in Russia, Geophys. Res. Lett., 37, L01801, doi:10.1029/2009GL041816, 2010.

Welton, E. J. and Campbell, J. R.: Micro-pulse Lidar Signals: Uncertainty Analysis, J. Atmos. Ocean. Tech., 19, 2089-2094, 2002.

Welton, E. J., Campbell, J. R., Spinhirne, J. D., and Scott, V. S.: Global monitoring of clouds and aerosols using a network of micro-pulse lidar systems, in: Lidar Remote Sensing for Industry and Environmental Monitoring, edited by: Singh, U. N., Itabe, T., and Sugimoto, N., (eds.), SPIE, 4153, 151-158, 2001. 